\title{
Pesantren Sebagai Bentuk Identitas Pendidikan Islam
}

\author{
Mahrus \\ Sekolah Tinggi Agama Islam Nahdhotul Ulama Malang \\ Email: mahrus87@gmail.com
}

\begin{abstract}
Islamic boarding school is one of the dominant Islamic education institutions and emphasizes religious studies that influence and impact the culture, tradition and preservation of Islamic teachings. Islamic boarding schools also play a role in the formation of a nation's civilization. Pesantren at this time must be prepared to face the challenges of globalization and produce graduates who can compete and fill the global era. For this reason, pesantren must be able to become institutions that are global in mind and have capable resources, especially in Islamic education. Therefore, it is necessary to change the mindset of pesantren into a mindset that follows change, which is oriented towards the creation of graduates who have three abilities, namely: (1) the ability to survive (survive) amidst continuous changes and competition, (2) the ability to improve the quality of life (spiritual and physical), (3) the ability to develop and adapt to the changing demands of the times.
\end{abstract}

Keywords: Islamic Boarding School, Islamic Education Identity

Abstrak: Pesantren adalah salah satu lembaga pendidikan Islam yang dominan dan menitikberatkan pelajaran agama yang berpengaruh dan berdampak pada kebudayaan, tradisi dan kelestarian ajaran Islam. Pesantren juga ikut berperan dalam terbentuknya peradaban suatu bangsa. Pesantren saat ini harus siap menghadapi tantangan globalisasi dan menghasilkan lulusan yang dapat bersaing dan mengisi era global. Untuk itu pesantren harus mampu menjadi institusi yang berwawasan global serta memiliki sumber daya yang mumpuni terutama dalam pendidikan Islam. Oleh karena itu perlu adanya perubahan pola pikir pesantren menjadi pola pikir yang mengikuti perubahan, yang berorientasi pada terciptanya lulusan yang memiliki tiga kemapuan, Yaitu: (1) kemampuan untuk survive (bertahan hidup) di tengah-tengah prubahan dan persaingan yang terus bergulir, (2) kemampuan untuk meningkatkan kualitas kehidupannya (rohaniyah dan jasmaniyah), (3) kemampuan untuk berkembang dan beradaptasi dengan tuntutan zaman yang terus berubah.

Kata Kunci: Pesantren, Identitas Pendidikan Islam 
Sejarah perkembangan peasantren telah memainkan pearan sekaligus kontribusi penting dalam sejarah pembangunan Indonesia. Sebelum kolonial Belanda datang ke Indonesia, pesantren merupakan suatu lembaga yang berfungsi menyebarkan agama Islam dan mengadakan perubahan-perubahan masyarakat kearah yang lebih baik. Sebagaimana tercermin dalam berbagai pengaruh pesantren terhadap kegiatan politik para raja dan pangeran di jawa, kegiatan perdagangan dan pembukaan daerah pemukiman baru. Ketika Belanda menduduki kerajaan-kerajaan di nusantara, pesantren menjadi pusat perlawanan dan pertahanan terhadap kolonial belanda, Jepang dan juga Inggris. Bahkan setelah kemerdekaan pun pesantren masih dikategorikan sebagai alat revolusi dan juga sebagai potensi pembangunan

Dewasa ini pandangan masyarakat umum terhadap pesantren dapat dibedakan menjadi dua macam. Pertama masyarakat yang menyangsikan eksistensi dan relevansi lembaga pesantren untuk menyongsong masa depan. Kedua masyarakat yang menaruh perhatian sekaligus harapan bahwa pesantren merupakan alternatife model pendidikan Islam masa depan.

Karena itu yang menjadi pertanyaan adalah bagaimana pesantren membangun jati diri dan tradisi sehingga eksis sampai sekarang. Nilai-nilai apa yang dikembangkan pesantren sehingga memiliki makna relasional dan relevansional terhadap setiap pembangunan yang ada. Sejatinya bagaimana pula mereposisi pesantren dalam konteks pendidikan Islam sehingga dapat menjawab tantangan zaman dan dapat memenuhi kebutuhan hidup masyarakat, serta bagaimana menciptakan pesantren modern yang bisa menintegrasikan ilmu umum dan ilmu agama.

\section{Tradisi Pendidikan Islam Pesantren

Sejarah
Pesantren

Pada awal rintisannya, pesantren bukan hanya menekankan misi pendidikan, melainkan juga dakwah, justru misi yang kedua ini yang lebih menonjol. Lembaga pendidikan tertua di Indonesia ini selalu mencari lokasi yang sekiranya dapat menyalurkan dakwah tersebut tepat saasaran sehingga terjadi benturan antara nilai-nilai yang dibawanya dengan nilai-nilai yang telah mengakar di masyarakat setempat. Mastuhu melaporkan bahwa periode awlanya pesantren berjuang melawan agama dan kepercayaan serba Tuhan dan tahayyul, pesantren membawa misi agama tauhid. (Matuhu, 1994, p.69)

Pesantren berjuang melawan perbuatan maksiat seperti perkelahian, perampokan, pelacuran, perjudian dan sebagainya. Akhirnya pesantren dapat membasmi perbuatan itu, kemudian mengubahnya menjadi masyarakat yang aman, tentram dan rajin beribadah. (Abu bakar Aceh, 1989, p.47) Pesantren berkembang terus sambil mengadapi rintangan demi rintangan. Sikap ini bukan ofensif melainkan tidak lebih defensif, hanya untuk menyelamatkan kehidupannya dan kelangsungan dakwah Islamiyah. Pesantren tidak pernah memulai konfrontasi sebab orientasi utamanya 
adalah melancarkan dan menanamkan pendidikan. Pada tahap berikut, pesantren diterima masyarakat sebagai upaya mencerdaskan, meningkatkan perdamaian dan membantu sosoipsikis bagi mereka. Tidak mengherankan jika pesantren menjadi kebanggaan masyarakat sekitarnya terutama yang sudah menjadi muslim. (Qomaar Mujamil, 2009, p.13)

Giliran selanjutnya, pesantren berhadapan dengan tindakan tiran kaum Kolonial Belanda. Imperealis yang menguasai Indonesia lebih dar tiga setengah abad ini selain menguasai polotik, ekonomi dan militer juga mengemban misi penyebaran agama Kristen. Bagi Belanda pesantren merupakan antitesis terhadap gerak kristenisasi dan upaya pembodohan masyarakat.anggapan demikian adalah sebagai basis argumentatif baginya untuk menekan pertumbuhan pesantren. Sutari Barnadip mengatakan bahwa penjajah malah mengahalang-halangi perkembangan agama Islam sehingga pondok pesantren tidak bisa berkembang secara normal. (Amir Hamzah, 1989, p.47)

Kemudian pada masa kemerdekaan pesantren merasakan nuansa baru. Kemerdekaan merupakan momentum bagi seluruh sistem pendidikan untuk berkembang lebih bebas, terbuka dan demokratis. Namun keadaan tersebut justru menjadai pukulan balik bagi pesantren. I Djumhur dan Dnasupatra mengisahkan bahwa lahirnya demokrasi memberi corak baru pada pendidikan agama. Pesantrenpesantren tidak lagi menjalankan tugasnya, sedangkan madrasah berkembang dengan sangat pesat. (I. Dhumhur dan Danasuparta, 2005, p.223) Kurun ini merupakan musibah paling dahsyat yang mengancam kehidupan dan kelangsungan pesantren. Hanya pesantrenpesantren besar yang mampu menghadapinya dengan mengadakan penyesuaian dengan sistem pendidikan nasional sehingga musibah itu dapat diredam.

\section{Sketsa Kondisi dan Potensi Pesantren}

Pesantren dalam dinamikanya dipandang mempunyai identitas tersendiri yang diistilahkan oleh Abdurrahman Wahid dengan subkultur. Secara jujur memang harus diakui bahwa terdapat tradisi tertentu yang tumbuh dan berkembang dalam masyarakat pesantren, namun tidak demikian kenyataannya di luar masyarakat pesantren. Tak ayal lagi sewaktu dunia luar mulai santer dengan isu modernisasi, maka keunikan dalam sunia pesantren tersebut menjadi salah satu penyebab mengapa tradisi pesantren semakin marak dan menarik untuk diperbincangkan. Implikasinya, dunia pesantren yang dalam kurun modern kurang begitu dikenal dan marginal, perlahan menjadi suatu hal yang menarik perhatian kalangan para ilmuan dan akademisi. (Mahmud Arif, 2008, p.167)

Tradisi pesantren dengan
kelebihan dan kekurangannya
merupakan khazanah dari budaya
bangsa, pesantren memiliki andil
besar dalam mempribumikan Islam
sehingga mudah dicerna dan
terhindar dari benturan konfliktual


pada awal masa kemunculan dan perkembangannya dengan budaya setempat. Melalui cara pewarisan tradisi Islam abad pertengahan dan akulturasi dengan budaya lokal. Dari sisi pola kesinambungan (continuity) dan perubahan (change) mendapat porsi seimbang sebagai implementasi dalam menumbuhkan masyarakat yang swadaya dan swasembada. (Abdul Munir Mulkhan, 2002, p.180) Terkait dengan sikap pesantren terhadap dunia luar (perubahan), terdapat asumsi bahwa pesantren alergi terhadap perubahan. Asumsi ini jelas tidak beralasan dan tidak mendasar. Sebab, akhir-akhir ini dinamika pesantren terbukti telah banyak yang jauh melampaui definisi awalnya dan fungsi tradisionalnya. (Kuntowijoyo, 2001, p.102) yakni sebagai lembaga keagamaan yang berfungsi sekedar sebagai tafaqahu fii ad diin dalam makna sempitnya dan sekedar berfungsi mentranskisikan ilmu-ilmu keislaman, memelihara tradisi Islam dan memproduksi ulama'.

Dalam beberapa segi pesantren sangat potensial untuk dikembangkan menjadai institusi keagamaan, pendidikan, dan kemasyarakatan yang cocok dengan kondisi budaya bangsa. Terlebih lagi pesantren terbukti mampu menampilkan diri sebagai institusi yang tetap eksis dalam menghadapi semua dinamika perubahan sosial dengan dua karakter utama pendidikannya., yaitu karakter budaya yang memungkinkan santri balajar secara tuntas, tidak hanya sebatas transfer ilmu pengetahuan tetapi juga pembentukan aspek kepribadian secara menyeluruh. Kedua kuatnya partisipasi masyarakat. (Mahmud Arif, 2008, p.167)

Nur Cholis majid dalam analisisnya menyatakan bahwa kesenjangan pesantren dengan modernisasi paling tidak dipicu oleh enam hal yang pada umumnya masih menandai kondisi obyektif pesantren yaitu: (Mahmud Arif, 2008, p.169) (1). Lingkungan, tata lingkuangan pesantren pada umumnya merupakan hasil pertumbuhan tak berencana, sporadis dan tidak memadai baik dari sisi kualitasnya maupun kuantitasnya. (2). penghuni/santri, adanya diskrepansi yang ditunjukan para santri bila dibandingkan dengan komunitas luar. (3). Kurikulum, pengajaran pengetahuan umum yang masih setengah-setengah. (4). Kepemimpinan, terdapat tolak ukur tertentu dalam kepemimpinan pesantren yaitu, karisma, personal, dan kurang mementingkan kecakapan teknis. (5). Alumni, para alumni pada umumnya hanya cocok untuk jenis masyarakat tradisional. (6). Kesederhanaan, walaupun kesederhanaan lekat dengan pesantren namun belum mendapat penekanan khusus dari kurikulumnya.

\section{Kultur Pesantren}

Eksistensi pesantren ditopang oleh kuatnya ikatan geneologi (silsilah) keilmuan antar kiayi pesantren, bahkan juga geneologi keturunan antar mereka, namun hal itu tidak membuahkan keseragaman. Pendidikan Islam pesantren mempunyai karakteristik tertentu. Setidaknya karakter itu tidak dimiliki sistem pendidikan lainnya, tetapi pesantren mengadopsi nilai-nilai yang berkembang di masyarakat. 
Keadaan ini oleh Abdurrahman Wahid disebut dengan istilah subkultur. Ada tiga elemen yang mampu membentuk pesantren sebagai subkultur: (1). Pola kepemimpina pesantren yang mandiri, tidak terkooptasi oleh Negara; (2). Kitab-kitab rujukan umum yang selalu digunakan dari berbagai abad; (3) Sistem nilai (value system) yang digunakan adalah bagian dari masyarakat luas. (Mahmud Arif, 2008, p.167)

Perpaduan fiqih-sufistik yang begitu kuat mempengaruhi budaya hidup dunia pesantren telah mengakibatkan munculnya pola pikir dan tata perilaku komunitas pesantren menyangkut khazanah pengetahuan Islam yang senantiasa berada dalam alur formulasi "normatife-mistis" salah satu implikasinya adalah proses belajar mengajar yang berlangsung di pesantren tampak lebih didominasi oleh model pemikiran deduktifdogmatis agama daripada pemikiran yang induktif rasional faktual. (Mastuhu, 1994, p.92) Sehingga penguasaan para santri akan didiplin keilmuan yang mendasari kemampuan ber-isti'dal dan beristimbath dari teks merupakan cirri pokok program kurikuler pesantren. Melalui sistem pembelajaran sorogan dan bandongan yang umum berlaku di dunia pesantren dengan pemberian makna gandul, yang disertai penjelasan gramatikal utawi iki iku dan dengan dangat menekankan analisis kebahasaan serta kurang memperhatikan analisis konteks/historis, maka pola reproduksi tersebut terasa semakin dikuatkan dalam proses transmisi keilmuan. Sebab sistem pembelajaran ini lebih menggambarkan bentuk komunikasi tatap muka, oral, dan personalmonolog. (Asep Saiful Muhtadi, 2004, p.85)

Dengan karakteristik tradisi keilmuan semacam itu, cukup beralasan sekiranya jika pesantren digolongkan ke dalam tradisi normatif. Menurut Kuntowijoyo, tradisi keilmuan normatif memilki dua kemungkinan yaitu deklaratif dan apologotis. (Kuntowijoyo, 2001, p.57)Tradisi normatif deklaratif mengarah pada orientasi dakwah dan semangat untuk menampilkan kemuliaan dan kebenaran ajaran Islam dengan argumentasiargumentasi doktrinal-teologis. Sementara itu tradisi normatifapologetis lebih banyak memuat pembelaan terhadap aspek-aspek tertentu dari ajaran Islam yang dideskriditkan oleh pihak luar.

Mastuhu mengidentifikasi prinsip-prinsip (moralitas) sistem pendidikan pesantren yang meliputi: teosentris, sukarela, mengabdi, kearifan, kesederhanaan, pengamalan ajaran agama dan restu sang kiayi. (Mastuhu, 1994, p.66) Moralitas semacam ini menunjukkan aspek penting pendidikan pesantren yaitu selalu memilki dimensi metafisik, pendidikan pesantren merupakan bagian dari sebuah perjalanan panjang pelatihan spiritual para santri.

\section{Kekhasan Pesantren}

Diakui memang bahwa tradisi pesantren telah melahirkan subkultur, namun bukan berarti ia adalah entitas otonom yang sama sekali tidak dapat disentuh oleh 
pergesseran dan perubahan (modernisasi) dari luar. Sebab eksistensi pesantren telah mempunyai kepentingan untuk memperoleh relevansi sosiologiskontekstual agar dapat tetap survive dan eksis. Akibat derasnya arus perubahan global, suka ataupun tidak pesantren harus bisa menerima logika perubahan dengan tetap teguh memegang tradisinya tanpa perlu bersikap tradisional.

Apabila dicermati secara seksama, pada setiap akhir kajian kitab kuning sebenarnya terdapat ungkapan wallahu a'lam bis shawaab (Allah yang maha mengetahui sesuatu yang benar) yang mengajarkan paham relatifesme-teosentris, yaitu paham bahwa kebenaran mutlak hanya pada wahyu Allah, sedangkan pemahaman manusia hanyalah relatife. (Mahmud Arif, 2008, p.190) Akan tetapi dalam kenyataanya, sering kali paham semacam itu kurang diapresiasi secara semestinya, sehingga dunia pesantren yang semestinya senantiasa membuka diri untuk bersikap kritis justru bersikap finalistik.

Di samping prestasi dan kekhasan dalam mengakrabi nilainilai universal kitab kuning, pesantren dalam sejarah perjalanannya hingga kini juga dinilai cukup berhasil mengukir prestasi dan kekhasan, terutama menyangkut: (1) Penghayatan mental spiritual keagamaan dan tafaqquh fi ad din, (2) Pelestarian nilai-nilai keagamaan, semisal: kesederhanaan, keikhlasan, ukhuwah, kebaktian dan keswadayaan, (3) Lebih condong pada pengutamaan sosial effect daripada civil effect, (4) Pelahiran pemimpin, baik formal maupun non formal yang berpengaruh di lingkungan masyarakat di sekitarnya, (5) Penyebarluasan dakwah Islam yang telah melahirkan umat Islam Indonesia sebagai mayoritas dari tata susunan masyarakat Indonesia. (Abdul Rahman saleh, 2000, p.225) Dalam perkembangan terakhir sistem pendidikan pesantren telah mengalami proses konvergensi dan sedikitnya dapat diklasifikasikan ke dalam lima tepe, yaitu: pertama, pesantren yang menyelenggarakan pendidikan formal dengan menerapkan kurikulm nasional baik yang hanya memiliki sekolah keagamaan maupun yang memiliki sekolah keagamaan dan sekolah umum: kedua, pesantren yang menyelenggarakan pendidikan keagamaan dalam bentuk madrasah dan mengajarkan ilmu-ilmu umum meski tidak menerapkan kurikulum nasional: ketiga, pesantren yang mengajarkan ilmu-ilmu agama dalam bentuk diniyah; keempat, pesantren yang hanya menjadi tempat pengajian (majlis taklim): kelima, pesantren yang disediakan untuk asrama mahasiswa dan pelajar sekolah umum. (Mahmud Arif, 2008, p.167) Selain hal tersebut, perubahan pesantren juga dipicu oleh semakin banyaknya keluhan-keluhan dari masyarakat yang mengindikasikan menurunnya (apresiasi) mereka terhadap pesantren. Secara riil, perubahan pesantren diakui memberikan dampak sosial yang luas dan signifikan. 


\section{Fungsi dan Peranan Pendidikan} Islam Pesantren

Pesantren pada masa yang paling awal berfungsi sebagai pendidikan dan pusat penyiaran agama Islam. Jika ditelusuri akar sejarah berdirinya sebagai kelanjutan dari pengemabangan dakwah, sebenarnya fungsi edukatif pesantren adalah sekedar membonceng misi dakwah. Misi dakwah Islamiyah inilah yang mengakibatkan terbangunnya sistem pendidikan. Pada masa wali songo unsur dakwah lebih dominan daripada unsur pendidikan. Fungsi pesantren semula mencakup tiga aspek yaitu fungsi religius (diniyyah), fungsi sosial (ijtimaiyyah), dan fungsi edukasi (tarbawinyyah). Fungsi lain adalah sebagai lembaga pembinaan moral dan kultural baik di kalangan para santri maupun santri dengan masyarakat. (Qomaar Mujamil, 2009, p.13)

Dalam masa penjajahan, pesantren memperluas fungsiny, berbagai fragmen film perjuangan senantiasa merekam dan menvisualkan fungsi sampingan ini. Kuntowijoyo menilai bahwa pesantren menjadi persemaian ideologi anti-belanda. Pesantren sebagai basis pertahanan bangsa dalam perang dalam melawan penjajah demi lahirnya kemerdekaan. Maka pendidikan pesantren berfungsi sebagai pencetak kader bangsa yang benar-benar patriotik, kader yang rela mati demi pemperjuangkan bangsa, sanggup mengorbankan seluruh waktu, harta bahkan jiwanya. (Kuntowijoyo, 1991, p.150)

\section{Dasar Pemikiran Pesantren Sebagai Lembaga Pendidikan Islam \\ Pesantren Sebagai Lembaga Pendidikan Islam}

Kehadiran kerajaan Bani Umaiyah menjadikan pesatnya ilmu pengetahuan, sehingga anak-anak Islam tidak hanya belajar di Mesjid tetapi juga pada lembaga ketiga yaitu "kuttab" yangartinya pesantren. Kuttab dengan karakteristik khasnya merupakan wahana dan lembaga pendidikan Islam yang semula sebagai lembaga baca dan tulis dengan sistem halaqah. Pada tahap berikutnya kuttab mengalami

perkembangan pesat karena didukung oleh dana dari iuran masyarakat serta adanya rencanarencana yang harus dipatuhi oleh pendidik dan peserta didik. ( Abdul Mudjib, 2006, p.228)

Dasar pesantren sebagai lembaga pendidikan Islam yaitu :

1) Pendidikan pesantren mencanangkan tujuan sebagai berikut :

2) Mencetak ulama yang menguasai ilmu-ilmu agama.

3) Mendidik muslim yang dapat melaksanakan syariat Islam. Lulusan pesantren walaupun mereka tidak sampai ke tingkat ulama tetapi mereka mempunyai kemampuan dalam melaksanakan syariat agama.

4) Mendidik objek agar memiliki keterampilan dasar yang relevan dengan terbentuknya masyarakat yang beragama.

Pandangan bahwa pendidikan pesantren perlu dikembangkan.

1) Karena adanya kenyataan peserta didik di sekolah umum 
diwajibkan belajar Pendidikan Agama Islam (PAI) sejak Taman Kanak-kanak hingga Perguruan Tinggi.

2) Integrasi nilai-nilai agama dengan perilaku dalam berbagai kawasan masyarakat mendorong adanya keperluan untuk mengintegrasikan nilai-nilai agama yang secara strategis bersumber dari AlQur'an dan Hadist nabi.

3) Munculnya kebutuhan akan adanya para ahli yang menguasai ilmu teknologi dengan perspektif Islam.

4) Lulusan pesantren meskipun tidak sampai ke tingkat ulama mereka mempunyai kemampuan yang lebih dari masyarakat kebanyakan dalam bidang agama. Sehingga mereka mempunyai kemampuan melaksanakan syariat agama Islam dalam rangka mengisi, membina dan mengembangkan suatu peradaban dalam perspektif Islam walaupun mereka tidak tergolong ulama yang menguasai ilmu-ilmu agama secara khusus. Dengan kata lain, aspek praktisnyalah yang dipentingkan. (Jusuf Amir Feisal, 1995, p.183)

Unsur-unsur Sebuah Pesantren

Di Indonesia ada ribuan lembaga pendidikan Islam terletak diseluruh nusantara dan dikenal sebagai dayah dan rangkang di

Aceh, surau di Sumatra Barat, dan pondok pesantren di Jawa). Pondok pesantren di Jawa itu membentuk banyak macam-macam jenis. Perbedaan jenis-jenis pondok pesantren di Jawa dapat dilihat dari segi ilmu yang diajarkan, jumlah santri, pola kepemimpinan atau perkembangan ilmu teknologi. Namun demikian, ada unsur-unsur pokok pesantren yang harus dimiliki setiap pondok pesantren. Unsurunsur pokok pesantren, yaitu kyai, mesjid, santri, pondok dan kitab Islam klasik (kitab kuning), adalah elemen unik yang membedakan sistem pendidikan pesantren dengan lembaga pendidikan lainnya. (Imam Hamidi Antassalam, 1995, p.190)

\section{a) Kyai}

Kyai merupakan unsur penting dalam pendirian, pertumbuhan, perkembangan, dan pengurusan sebuah pesantren. Sebagai pemimpin pesantren, watak dan keberhasilan pesantren banyak bergantung pada keahlian dan kedalaman ilmu, karismatik dan wibawa, serta keterampilan kyai.

\section{b) Masjid}

Sangkut paut pendidikan Islam dan mesjid sangat dekat dan erat dalam tradisi Islam di seluruh dunia. Dahulu, kaum muslimin selalu memanfaatkan masjid untuk tempat beribadah dan juga sebagai tempat lembaga pendidikan Islam. Sebagai pusat kehidupan rohani,sosial dan politik.masjid merupakan aspek kehidupan sehari-hari yang sangat penting bagi masyarakat. Oleh karena itu, mesjid dianggap tempat yang sangat tepat untuk mendidik para santri dalam bidang pendidikan khususnya dalam bidang pendidikan Islam.

\section{c) Santri}

Santri juga merupakan unsur yang penting sekali dalam perkembangan sebuah pesantren karena langkah pertama dalam tahap-tahap membangun pesantren adalah bahwa harus ada murid yang datang untuk belajar dari seorang alim. Kalau murid itu 
sudah menetap di rumah seorang alim, baru seorang alim itu bisa disebut kyai dan mulai membangun fasilitas yang lebih lengkap untuk pondoknya.

d) Pondok

Pondok merupakan tempat kediaman kyai dan para santri. Selain itu pondok juga digunakan sebagai tempat latihan bagi santri untuk mengembangkan keterampilan dan kemandiriannya agar mereka siap hidup mandiri dalam masyarakat sesudah tamat dari pesantren. Santri harus memasak sendiri, mencuci pakaian sendiri dan diberi tugas seperti memelihara lingkungan pondok.

e) Kitab Islam klasik (Kitab Kuning)

Kitab-kitab Islam klasik yaitu kitab yang dikarang para ulama terdahulu dan termasuk pelajaran mengenai macam-macam ilmu pengetahuan agam Islam dan Bahasa Arab. Dalam kalangan pesantren, kitab-kitab Islam klasik sering disebut kitab kuning oleh karena warna kertas edisi-edisi kitab kebanyakan berwarna kuning.

Pesantren adalah lembaga pendidikan Islam tertua yang telah berfungsi sebagai salah satu benteng pertahanan umat Islam, pusat dakwah dan pusat pengembangan masyarakat muslim. Secara informal lembaga pesantren di Indonesia berfungsi sebagai keluarga yang membentuk watak dan pekribadian santri. Pesantren juga telah melaksanakan pendidikan keterampilan melalui kursus-kursus untuk membekali dan membantu kemandirian para santri dalam kehidupan masa depannya sebagai muslim dan juga dai dan Pembina masyarakat. Secara keseluruhan pesantren selalu dijadikan contoh dan panutan oleh masyarakat, sehingga keberadaan pesantren di Indonesia telah berperan menjadi potensi yang sangat besar dalam pengembangan masyarakat. Sebagai lembaga pendidikan Islam pesantren memiliki lima elemen pokok, yaitu: pondok tempat penginapan santri, masjid, santri, pengajaran kitab-kitab klasik dan kiyai.

Prinsip-prinsip pendidikan yang diterapkan di pesantren di antaranya yaitu:

1) Filsafat pendidikan teosentris, yaitu suatu pandangan yang menyatakan bahwa semua kejadian, proses kembali pada kebenaran Tuhan

2) Kesukarelaan (keikhlasan) dan pengabdian

3) Kearifan hidup

4) Kesederhanaan

5) Hubungan santri, guru, orangtua dan masyarakat

6) Mengatur kegiatan bersama

7) Kebebasan terpimpin

8) Kemandirain

9) Mengamalkan ajaran agama

10) Ilmu pengetahuan diperoleh di samping dengan ketajaman akal juga sangat tergantung kepada kesucian hati dan berkah kiyai.

\section{Sejarah Pesantren di Indonesia}

Secara terminologis dapat dijelaskan bahwa pendidikan pesantren dilihat dari segi bentuk dan sistemnya berasal dari India. Sebelum proses penyebaran Islam di Indonesia, sistem tersebut telah digunakan secara umum untuk pendidikan dan pengajaran agama 
Hindu. Setelah Islam masuk dan tersebar di indonesia, sistem tersebut kemudian diambil oleh Islam. Namun bila kita menengok waktu sebelum tahun 60-an, pusat-pusat pendidikan tradisional di Indonesia lebih dikenal dengan sebutan pondok, barangkali istilah pondok berasal dari kata Arab funduq, yang berarti penginapan bagi para musafir. Kata pesantren sendiri berasal dari akar kata santri dengan awalan "Pe" dan akhiran "an" berarti tempat tinggal para santri.

$$
\text { Potret Pesantren pada }
$$
dasarnya adalah sebuah asrama pendidikan Islam tradisional dimana para siswanya tinggal bersama dan belajar ilmu-ilmu keagamaan di bawah bimbingan guru yang lebih dikenal dengan sebutan kyai. Asrama untuk para siswa tersebut berada dalam komplek pesantren dimana kyai bertempat tinggal. Disamping itu juga ada fasilitas ibadah berupa masjid. Biasanya komplek pesantren dikelilingi dengan tembok untuk dapat mengawasi arus keluar masuknya santri. Dari aspek kepemimpinan pesantren kyai memegang kekuasaan yang hampir mutlak.

\section{Kelemahan Pesantren}

Sudah terbukti selama berabad-abad lamanya, institusi pendidikan yang mampu memproduksi manusia-manusia yang berbudi pekerti luhur, berilmu dan beramal hanyalah pendidikan yang bersistem kepesantrenan. Walaupun sistem ini belumlah bisa diberi nilai sempurna karena pesantren masih cenderung defensif terhadap perkembangan zaman. Beberapa kelemahan dari pesantren antara lain sebagai berikut:

1. Banyak pesantren yang tidak dapat mencapai tujuan pendidikannya, yaitu mencetak kader ulama sekaligus pemimpin umat dan pemimpin bangsa.

2. Umumnya pendidikan pesantren tidak memiliki sarana dan prasarana yang cukup memadai (fisik, personal dan finansial). Masalah kelangkaan sarana dan prasarana sebenarnya dapat diatasi dengan kerjasama lintas sektoral, seperti kerjasama antar lembaga pendidikan yang tidak sejenis dan kerjasama umat dalam hal menyisihkan dana dari penghasialn mereka.

3. Lembaga pesantren memiliki kesan tradisional, sehingga tidak menjadi pilihan untuk kemajuan. Kesan tradisional sebenarnya mitos hanya karena lulusan pesantren tidak semua diangkat menjadi pegawai negeri. Sebenarnya, banyak lulusan pesantren dapat menciptakan lapangan kerja sandiri, misalnya mendirikan mendirikan pesantren sendiri. Meskipun demikian kesan tradisional akan tumbuh terus apabila lulusan pesantren tidak memiliki kepribadian yang kompetitif dengan lulusan pendidikan lain.

4. Pemilikan lembaga oleh keluarga atau kelompok. Pemilikan lembaga oleh keluarga atau kelompok tidak akan berdosa apabila lulusannya memiliki daya fastabiqul khairat (kompetensi dalam kebenaran).

5. Pesantren dikesankan ekslusif. 
6. Pengelolaan pesantren cenderung kurang professional. Pengelolaan proses pendidikan pesantren secara professional dapat dilakukan dengan cara sebagai berikut:

7. Kerjasama antar pesantren.

8. Studi banding antara lembaga pendidikan pesantren dengan lembaga pendidikan umum.

9. Menggunakan teknologi canggih yang sudah dapat dikuasai seperti komputer, tenaga professional, menentukan cangkupan bahan ajar dan sebagainya.

10. Melakukan rencana program studi tahunan.

11. Mengkaji ulang cangkupan bahan ajar.

\section{Kelebihan Pesantren}

Dalam catatan sejarah, pesantren dinilai tidak hanya mengandung nilai keislaman saja, tetapai juga mengandung makna keaslian Indonesia. Kenyataan ini tidak lepas dari proses panjang islamisasi yang dilalui, dimana pesantren ikut terlibat didalamnya. Selama proses tersebut pesantren dengan canggih telah melakukan akomodasi dan transformasi sosiokultural terhadap pola kehidupan masyarakat sekitar. Kelebihan pesantren antara lain sebagai berikut:

$$
\text { Lembaga pendidikan }
$$

pesantern masih diterima sebagai lembaga pendidikan alternatif. Lamanya waktu pertumbuhan dan perkembangan Islam di Indonesia serta berhasilnya proses dakwah mempertahankan kesepakatan bahwa lembaga pendidikan Islam masih perlu ditingkatkan dari tahun ke tahun. Selain itu keterbatasan tempat dan kurang cerahnya harapan lulusan sekolah umum menolong kedudukan lembaga pendidikan pesantren melaksanakan program studinya, baik secara menyeluruh maupun trebatas.

1. Kuantitas lembaga pendidikan pesantren memiliki jumlah yang lebih besar daripada lembaga pendidikan umum.

2. Adanya tradisi keagamaan dan kepemimpinan pada pesantren yang merupakan potensi nasional untuk pembangunan, khususnya pembinaan keimanan dan ketakwaan yang menjadi tujuan pendidikan nasional.

3. Terbuka untuk pembaharuan.

4. Keakraban antar santri dan kyai yang sangat kondusif bagi pemerolehan pengetahuan yang hidup.

5. Kemampuan pesantren mencetak lulusan yang punya kemandirian.

6. Kesederhanaan gaya hidup komunitas pesantren. (Jusuf Amir Feisal, 1995, p.183)

$$
\text { Jadi dapat disimpulkan }
$$

kelebihan dari pesantren yaitu: a) pesantren unggul dengan produktifitasnya dalam menghasilkan pribadi-pribadi yang berakhlaqul karimah, b) sistem pondoknya memungkinkan pendidik (kyai) melakukan tuntunan dan pengawasan langsung pada santrinya, c) keterikatan psikologis orang tua muslim dengan lembagalembaga pendidikan agama masih kuat.

\section{Pesantren Dahulu dan Masa Kini}

Dalam catatan sejarah, pesantren dikenal di Indonesia sejak zaman Walisongo. Ketika itu Sunan Ampel mendirikan sebuah padepokan di Ampel Surabaya dan 
menjadikannya pusat pendidikan di Jawa. Para santri yang berasal dari pulau Jawa datang untuk menuntut ilmu agama. Bahkan di antara para santri ada yang berasal dari Gowa, Talo dan Sulawesi. Pesantren Ampel merupakan cikal bakal berdirinya pesantren-pesantren di Tanah Air. Sebab para santri setelah menyelesaikan studinya merasa berkewajiban mengamalkan ilmunya di daerahnya masing-masing. Maka didirikanlah pondok-pondok pesantren dengan mengikuti pada apa yang mereka dapatkan di pesantren Ampel.

Kesederhanaan pesantren dahulu sangat terlihat, baik segi fisik bangunan, metode, bahan kajian dan perangkat belajar lainnya. Hal itu dilatarbelakangi kondisi masyarakat dan ekonomi yang ada pada waktu itu. Ciri khas dari lembaga ini adalah rasa keikhlasan yang dimiliki para santri dan sang kyai. Hubungan mereka tidak hanya sekedar sebagai murid dan guru, tapi lebih seperti anak dan orang tua. Bentuk keikhlasan itu terlihat dengan tidak dipungutnya sejumlah bayaran tertentu dari para santri, mereka bersama-sama bertani atau berdagang dan hasilnya dipergunakan untuk kebutuhan hidup mereka dan pembiayaan fisik lembaga, seperti lampu, bangku belajar, tinta, tikar dan lain sebagainya.

Materi yang dikaji adalah ilmu-ilmu agama, seperti fiqih, nahwu, tafsir, tauhid, hadist dan lainlain. Biasanya mereka mempergunakan rujukan kitab kuning. Di antara kajian yang ada, materi nahwu dan fiqih mendapat porsi mayoritas. Ha litu karena mereka memandang bahwa ilmu nahwu adalah ilmu kunci. Seseorang tidak dapat membaca kitab kuning bila belum menguasai nahwu. Sedangkan materi fiqih karena dipandang sebagai ilmu yang banyak berhubungan dengan kebutuhan masyarakat (sosiologi). Tidak heran bila sebagian pakar meneybut sistem pendidikan Islam pada pesantren dahulu bersifat "fiqih orientied" atau "nahwu orientied".

Masa pendidikan tidak tertentu, yaitu sesuai dengan keinginan santri atau keputusan sang Kyai bila dipandang santri telah cukup menempuh studi padanya. Biasanya sang Kyai menganjurkan santri tersebut untuk nyantri di tempat lain atau mengamalkan ilmunya di daerah masing-masing. Para santri yang tekun biasanya diberi "ijazah" dari sang Kyai.

Lokasi pesantren model dahulu tidaklah seperti yang ada kini. Ia lebih menyatu dengan masyarakat, tidak dibatasi pagar (komplek) dan para santri berbaur dengan masyarakat sekitar. Bentuk ini masih banyak ditemukan pada pesantrenpesantren kecil di desa-desa Banten, Madura dan sebagian Jawa Tengah dan Timur.

Bentuk, sistem dan metode pesantren di Indonesia dapat dibagi kepada dua periodisasi yaitu pertama, periode Ampel (salaf) yang mencerminkan kesederhanaan secara komprehensif. Kedua, Periode Gontor yang mencerminkan kemodernan dalam sistem, metode dan fisik bangunan. Periodisasi ini tidak menafikan adanya pesantren sebelum munculnya Ampel dan Gontor. Sebelum Ampel muncul, telah berdiri pesantren yang dibina 
oleh Syaikh Maulana Malik Ibrahim. Demikian juga halnya dengan Gontor, sebelumnya telah ada. Justru yang menjadi cikal bakal Gontor adalah pesantren Tawalib, Sumatera. Pembagian di atas didasarkan pada besarnya pengaruh kedua aliran dalam sejarah kepesantrenan di Indonesia. (Muhammad Jamhuri, 1995, p.201)

Sifat kemodernan Gontor tidak hanya terletak pada bentuk penyampaian materi yang menyerupai sistem sekolah atau perkuliahan di perguruan tinggi, tapi juga pada gaya hidup. Hal ini tercermin dari pakaian santri dan gurunya yang mengenakan celana dan dasi. Berbeda dengan aliran Ampel yang sarungan dan sorogan. Hal ini bisa dimaklumi, mengingat para Kyai salaf menekankan perasaan anti kolonial pada setiap santri dan masyarakat, hingga timbul fatwa bahwa memakai celana dan dasi hukumnya haram berdasarkan sebuah hadist yang berbunyi: "Barang siapa yang menyerupai suatu kaum (golongan), maka dia termasuk golongan itu".

Dalam hal ini, Gontor telah berani melangkah maju menuju perubahan yang saat itu masih dianggap tabu. Namun demikian bukan tidak beralasan. Penggunaan dasi dan celana yang diterapkan Gontor adalah untuk mendobrak mitos bahwa santri selalu terkebelakang dan ketinggalan zaman. Prinsip ini tercermin dengan masuknya materi bahasa inggris menjadi pelajaran utama setelah bahasa Arab dan agama, dengan tujuan agar santri dapat mengikuti perkembangan zaman dan mampu mewarnai masyarakat dengan segala perubahannya.

Beberapa reformasi dalam sistem pendidikan pesantren yang dilakukan Gontor antara lain dapat disimpulkan pada beberapa hal. Di antaranya: tidak bermazdhab, penerapan organisasi, sistem kepimimpinan sang Kyai yang tdak mengenal sistem waris dan keturunan, memasukkan materi umum dan bahasa Inggris, tidak mengenal bahasa daerah, penggunaan bahasa Arab dan Inggris sebagai bahasa pengantar dan percakapan, olah raga dengan segala cabangnya dan lain-lain. Oleh karena itu Gontor mempunayi empat prinsip, yaitu: berbudi tinggi, berbadan sehat, berpikiran bebas dan berpengetahuan luas.

Langkah-langkah reformasi yang dilakukan Gontor pada gilirannya melahirkan alumni-alumni yang dapat diandalkan, terbukti dengan duduknya para alumni Gontor di berbagai bidang, baik di instansi pemertintah maupun swasta. Bila mazdhab Ampel telah melahirkan para ulama, pejuang kemerdekaan dan mereka yang memenuhi kebutuhan lokal, maka Gontor telah memenuhi kebutuhan di segala bidang kehidupan di negeri ini.

Satu persamaan yang dimilki dua mazdhab ini adalah bahwa kedua-duanya tidak mengeluarkan ijazah negeri kepada alumninya, dengan keyakinan bahwa pengakuan masyarakatlah sebagai ijazahnya. 


\section{Pendidikan Islam Pesantren Dalam Tuntutan Perubahan Geneologi Ideologis Pesantren}

Pigeaud dalam Java in the

Fourteenth Century dan Denis Lombard dalam Nusa Jawa Silang Budaya mengatakan bahwa pesnatren merupakan kesinambungan suatu lembaga pendidikan dan keagamaan pra-Islam atau pendidikan budaya HinduBudha. (Imam Tolkhah dan Ahmad Barizi, 2004, p.51) Sementara zamakhsary Dhofier mengatakan bahwa pesantren merupakan model pendidikan Islam yang diadopsi dari sistem pendidikan di Timur Tengah. Jadi, dengan demikian dapat disimpulkan bahwa pesantren sebagai model pendidikan merupakan "proses pelarutan" sistem pendidikan Islam di Timur tengah dan sekolah Hindu-Budha di Jawa. (Imam Tolkhah dan Ahmad Barizi, 2004, p.51) Tidak sedikit lembaga pendidikan model mandala milik Hindu-Budha yang kemudian waktu dikuasai oleh kerajaankerajaan Islam dimodifikasi sebagai model pendidikan Islam di Jawa, seperti langgar dan masjid.

Tidak sedikit konstribusi yang diberikan pesantren dalam pembangunan nation-state selama ini. Pertama, pada masa penjajahan pesantren memainkan peran perlawanan dan mengambil uzlah sebagai bentuk strategi perlawanan kepada dan sekaligus pertahanan dari penjajah. Kedua, pada masa pergerakan dan persiapan kemerdekaan. Pesantren berperan sebagai pusat perjuangan/gerilyawan seperti Hizbullah dan Sabilillah. Ketiga, sejak abad ke-20M pesantren baru mereposisi diri kearah sistem pendidikan yang beorientasi masa depan tanpa menghilangkan tradisitradisi baik seebelumnya.

\section{Nilai-Nilai Pesantren}

Komunitas keagamaan pesantren dilandasi oleh keinginan ber-tafaqquh fi al din (mendalami atau mengkaji agama) dengan kaidah al-muhafadzah ala al qadim al shalih wa al akdzu bil jadidi al ashlah (memelihara tradisi lama yang baik dan mengambil tradisi baru yang lebih baik). Keinginan kaidah ini merupakan nilai pokok yang melandasi kehidupan dunia pesantren. (Imam Tolkhah dan Ahmad Barizi, 2004, p.55)

Eksistensi pesantren menjadi kokoh karena dijiwai dengan apa yang dikenal dengan panca-jiwa pesantren yaitu: Pertama, jiwa keikhlasan. Yaitu jiwa kepesantrenan yang tidak didorong oleh ambisi apapun untuk memperoleh keuntungan-keuntungan tertentu khususnya secara material, melainkan semata-mata karena ibadah karena Allah. Kedua, Jiwa kesederhanaan. Kata sederhana di sini bukan berarti pasif, melarat, miskin dan menerima apa adanya, tetapi mengandung unsur kekuatan dan ketabahan hati, kemampuan mengendalikan diri dan kemampuan menguasai diri dalam menghadapi kesulitan. Ketiga, Jiwa kemandirian yaitu kesanggupan membentuk kondisi pesantren sebagai institusi pendidikan Islam yang merdeka dan tidak menggantungkan diri kepada bantuan dan pamrih pihak lain. Keempat, jiwa bebas, mengandaikan sivitas pesantren sebagai manusia yang kokoh dalam memilih jalan hidup dan masa depannya dengan 
jiwa besar dan sikap optimis dalam mengahadapi problematika kehidupan dengan nilai-nilai Islam. Kelima, jiwa ukuhuwah Islamiyah. Yaitu memanifestasi dalam keseharian sivitas pesantren yang bersifat dialogis, penuh kekaraban, penuh kompromi dan toleransi. (Imam Tolkhah dan Ahmad Barizi, 2004, 57)

Sejumlah nilai di atas menjadikan pesantren eksis sepanjang sejarah kehidupan dan dinamika zaman. Globaslisasi teknologi industri yang mendunia tidak menggoyahkan eksistensi pesantren sebagai penjaga dan sekaligus pelestari nilai-nilai. Kenapa demikian? Karena pesantren hanya bergantung kepada kebenaran mutlak (Tuhan) yang diaktualisasikan dalm tradisi yang bercorak fiqih-sufistik, berorientasi pada amalan ukhrawi dan kepada kebenaran relatif yang bercorak empiris dan pragmatis untuk memecahkan berbagai persoalan kehidupan sesuai dengan hukum agama. (Imam Tolkhah dan Ahmad Barizi, 2004, 58)

\section{Sistem Pendidikan Islam Pesantren \\ Sistem Pandidikan Independen}

Pendidikan Islam pesantren mempunyai karakteristik tertentu. Setidaknya karakter itu tidak dimiliki sistem pendidikan lainnya, tetapi pesantren mengadopsi nilai-nilai yang berkembang di masyarakat. Keadaan ini oleh Abdurrahman Wahid disebut dengan istilah subkultur. Ada tiga elemen yang mampu membentuk pesantren sebagai subkultur : 1 . Pola kepemimpina pesantren yang mandiri, tidak terkooptasi oleh Negara; 2. Kitab-kitab rujukan umum yang selalu digunakan dari berbagai abad; 3 Sistem nilai (value system) yang digunakan adalah bagian dari masyarakat luas. (Departemen Agama RI, 1984/1985, p.83)

Secara esensial, sistem pendidikan Islam pesantren yang dianggap khas ternyata bukan sesuatu yang baru jika dibandingkan dengan sistem pendidikan sebelumnya. I.P Simanjuntak menegaskan bahwa masuknya Islam tidak mengubah hakikat pengajaran agama yang formil. Perubahan yang terjadai sejak pengembangan Islam hanyalah menyagkut isi agama yang dipelajari, bahasa yang menjadi wahana bagi pelajaran agama itu, dan latar belakang para santri. (Imron Arifin, 1993, p.37) Dengan demikian sistem pendidikan yang dikembangkan pesantren dalam banyak hal merupakan hasil adaptasi dari pola-pola pendidikan yang telah ada dikalangan masyarakat HinduBudha sebelumnya. Jika ini benar, ada relevansinya denagn suatu statement bahwa pesantren mendapat pengaruh dari tradisi lokal.

Proses adaptasi sistem pendidikan pesantren itulah yang menguatkan penilaian selama ini bahwa pendidikan pesantren disebut sistem pendidikan produk Indonesia. Selanjutnya pesantren merupakan sistem pendidikan yang melakukan kegiatan sepanjang hari. Santri tinggal di asrama dalam satu kawasan bersama guru, kiai dan senior mereka. Oleh karena itu hubungan yang terjalin antara santriguru-kiai dalam proses pendidikan berjalan intensif, tidak sekedar 
hubungan formal ustad-santri di dalam kelas. Dalam sistem pendidikan ini membawa banyak keuntungan antara lain: pengasuh dapat melakukan pemantauan secaa leluasa hampir setiap saat terdapat perilaku santri baik yang terkait dengan pengembangan intelektualnya maupun kepribadiannya. Keuntungan kedua adalah adanya proses pembelajaran dengan frekuensi yang tinggi dapat memperkokoh pengetahuan yang diterimanya. Keuntungan ketiga adalah adanya proses pembiasaan akibat interaksi setiap saat baik sesama santri, santri dengan ustad, maupun santri dengan kiai. Keuntungan lain lagi adalah adanya integrasi antara proses pembelajaran dengan kehidupan keseharian.

Sebagai lembaga pendidikan Islam, tampak jelas bahwa prinsipprinsip pendidikan di pesantren bersifat teosentris. Orientasi pendidikan pesantren memusat pada sikap taqarrub (mendekatkan diri kepada Allah dengan keteguhan dan ketaatan beribadah serta melaksanakan doktrin-doktrin agama secara ketat) dan sikap tahassun (melaksanakan amal-amal saleh, baikk kesalehan individual, maupun kesalehan sosial dan perilaku yang etis serta bermanfaat). (M. Tolhah Hasan, 1996, p.38) Maka pesantren sering dinilai terlalu mementingkan orientasi kehidupan ukhrawi dan kurang berorientasi pada pendidikan keduniawian. Jika pendidikan nasional berorientasi pada antroposentris, maka sistem pendidikan pesantren lebih berorientasi pada teosentris.

\section{Kurikulum Pendidikan Islam Pesantren}

Kurikulum pengajaran berupa inti ajaran Islam yang mendasar. Rangkaian trio komponen ajaran Islam yang berupa iman, Islam dan ihsan atau doktrin, ritual telah menjadi perhatian kiayi perintis sebagai kurikulum yang diajarkan kepada santrinya. Isi pengajian itu berkisar pada soal rukun iman, rukun Islam, akhlak dan ilmu hikmah atau tasawuf. (Aya Sofia, 2004, p.41)

Mahmud yunus mencatat, ilmu yang mula-mula diajarkan di pesantren adalah ilmu sharaf dan nahwu, kemudian ilmu fiqih, tafsir, ilmu kalam (tauhid), akhirnya sampai pada ilmu tasawwuf dan sebagainya. (Mahmud yunus, 1985, p.232) Betapapun kecilnya, pengembangan isi kurikulum ini telah membuktikan adanya gerak kemajuan yang mengarah pada pemenuhan kebutuhan santri terutama sebagai pembentukan intelektual di samping pengembangan kepribadian. Dalam perkembangannya ilmu-ilmu dasar keislaman seperti tauhid, fiqih dan tasawuf selalu menjadi mata pelajaran favorit bagi para santri. Tauhid memberikan pemahaman dan keyakinan terhadap keesaan Allah, fiqih pemberikan cara-cara beribadah sebagai konsekuensi logis dari keimanan yan gtelah dimiliki seseorang, sedangkan tasawuf membimbing seseorang pada penyempuranaan ibdah agar menjadi orang-orang yang benar-benar dekat pada Allah.

Kemudian kurikulum pesantren berkembang menjadi tambah luas lagi dengan penambahan ilmu-ilmu yang masih merupakan elemen dari materi pelajaran yang 
diajarkan pada masa awal pertumbuhannya. Pengembangan kurikulum tersebut lebih bersifat rincian materi pelajaran yang sudah ada daripada penambahan disiplin ilmu yang baru sama sekali. Beberapa laporan mengenai materi pelajaran tersebut dapat disimpulkan: Al Qur'an dengan tajwid dan tafsirnya, Aqoid dan ilmu kalam, Fiqih dengan ushul fiqih dan Qowaid al fiqh, hadist dengan mustholahah hadist, bahasa dengan ilmu alatnya seperti nahwu, shorof, bayan, ma'ani, badi' dan 'arud,tarikh, mantiq, tasawuf, akhlak dan falak.

Titik pusat pengembangan keilmuan di pesantren adalah ilmuilmu agama, tetapi ilmu agama tidak akan berkembang dengan baik tanpa ditunjang dengan ilmu-ilmu lain (ilmu-ilmu social, humaniora dan kealaman). Maka oleh sebagian pesantren ilmu-ilmu tersebut juga diajarkan. Ilmu-ilmu tersebut sebagai penunjang dari ilmu-ilmu agama, maka orientasi keilmuan pesantren tetap berpusat pada ilmu-ilmu agama. (Haidar Putra Daulay, 2001, p.30)

\section{Penutup}

Pesantren merupakan lembaga pendidikan yang memiliki beberapa fungsi diantara adalah fungsi Tafaqquh fi al-din (pendalaman pengetahuan tentang agama) fungsi Tarbiyah al akhlaq (pembentukan kepribadian / budi pekerti) dan fungsi pengembangan masyarakat atau pusat rehabilitasi sosial. Hanya saja dalam konteks pendidikan tepat proses belajar mengajar konsep tafaqquh fi al din kurang mendapat porsi yang semesti yangg terjadi di pesantren penekanan bukan pada Tafaqquh fi al din tetapi sekedar transfer ilmu pengetahuan.

Inti atau penekanan pendidikan pondok pesantren sebagai wadah dan tempat tercapai suatu pendidikan Islam Indonesia yakni tercapai tujuan pembangunan nasional bidang pendidikan. Secara realistis banyak kalangan menilai bahwa sistem pendidikan yang berlangsung di tanah air ini masih belum mampu mengantarkan tercapai pendidikan Islam yaitu membangun manusia Indonesia seutuhnya. . Berpijak dari konsep dasar itulah pendidikan pondok pesantren mencoba memberikan respon dalam menanggapi sistem pendidikan yang ada di tanah air ini dan dituntut ada penyikapan yang arif dan bijaksana. Sehingga pesantren bisa menjadi bentuk identitas dari pendidikan Islam.

Dalam melaksanakan sistem dan proses pengajaran pendidikan pondok pesantren dalam perspektif pendidikan Islam Indonesia mempunyai peran serta memiliki unsur-unsur atau kontribusi pemikiran terhadap berkembang dan tumbuh pendidikan Islam. Pendidikan di pesantren ada kelemahan dan kelebihan tapi jika pesantren mampu mengeleminir kelemahan tersebut dan mengoptimalkan kelebihan maka bukan tak mungkin ia menjadi salah satu alternatif yang cukup menjanjikan dimasa masa yang akan datang terutama ditengah pengap system pendidikan nasional yang cenderung lebih menekankan pada education for the brain dan relatif mengabaikan Education for The heart yang giliran hampir bisa dipastikan akan menghasilkan over 
educated society kian membludak pengangguran elit intelektual meraksasa dalam tehnik tapi merayap dalam etik pongah dengan pengetahuan tapi bingung dalam menikmati kehidupan cerdas otak tapi bodoh nuraninya.

$$
\text { Inti atau penekanan }
$$
pendidikan pondok pesantren sebagai wadah dan tempat tercapai suatu pendidikan Islam Indonesia yakni tercapai tujuan pembangunan nasional bidang pendidikan. Secara realistis banyak kalangan menilai bahwa sistem pendidikan yang berlangsung di tanah air ini masih belum mampu mengantarkan tercapai pendidikan Islam yaitu membangun manusia Indonesia seutuhnya. . Berpijak dari konsep dasar itulah pendidikan pondok pesantren mencoba memberikan respon dalam menanggapi sistem pendidikan yang ada di tanah air ini dan dituntut ada penyikapan yang arif dan bijaksana.

\section{Daftar Rujukan}

Abdurrahman Muslim 1985, Pendidikan Pesantren dalam Perspektif Pengembangan Ilmu dan Msyarakat, Jakarta: P3M.

Arif Mahmud. 2008. Pendidikan Islam Transformatif, Yogyakarta: Pelangi Aksara.

Abdul Mudjib, Ilmu Pendidikan Islam, 2006 Jakarta : Kencana Prenada Media,

Abu bakar Aceh, 1989, Sejarah hidup KH A Wahid Hasyim dan Karangan

Tersiar, Jakarta: Mulia Ofcet
Abdul Munir Mulkhan, 2002, Nalar Spiritual Pendidikan, Solusi Problem

Filosofis Pendidikan Islam, Yogyakarta: Tiara Wacana

Amir Hamzah, 1989, Perubahan Pendidikan dan Pengajaran Islam, Jakarta: Mulia Offcet

Dhumhur dan Danasuparta 20005, Sejarah pendidikan, Bandung: CV Ilmu 223

Imam Hamidi Antassalam, 1995 UnsurUnsur Pesantren, Jakarta : Gema Insani

Imron Arifin, 1993, Kepemimpinan Kiai Kasus Pondok Pesantren Tebu Ireng, Malang: kalimasahada press,

Jusuf Amir Feisal, 1995 Reorientasi Pendidikan Islam, Jakarta : Gema Insani

Kuntowijoyo. 1991. Paradigma Islam interpretasi Untuk Aksi. Bandung; mizan.

Mahmud Arif, 2008, Pendidikan Islam Transformatif, Yogyakarta: Pelangi

Aksara

Mulkhan, Abdul Munir. 2002. Nalar Spiritual Pendidikan, Solusi Problem Filosofis Pendidikan Islam, Yogyakarta: Tiara Wacana.

Mastuhu. 1997. Dinamika sistem Pendidikan Pesantren Suatu Kajian Tentang unsur dan Nilai Sistem Pendidikan Pesantren. Bandung: Mizan

Muhammad Husen, 1999.
Kontekstualisasi $\quad$ Kitab
Kuning: Tradisi Kajian dan
Metode
Bandung: Pustaka Hidayah.


Muhammad Jamhuri, 2009 Pondok Pesantren: sejarah dan Perkembangan Pendidikan Islam di Indonesia, Jakarta : Gema Insani

Mujamil, Qomar. 2009, Pesantren dari Tranformasi Metodologi Menuju Demokratisasi Institusi, jakarta:Erlangga.

Saiful Muhtadi Asep, 2004. Komunikasi Politik Nahdatul ulama': Perhulatan Pemikiran Radikal dan Akomodatif, Jakarta: LP3ES

Saleh Abdul Rahman, 2000. Pendidikan Agama dan Keagamaan: visi, misi dan aksi, Jakarta: Gemawindu Pancaperkasa.
Tolkhah Imam dan Ahmad Barizi, 2004. Membuka Jendela Pendidikan: Mengurai Akar Tradisi dan Integrasi Keilmuan Pendidikan Islam, Jakarta: Raja Grafindo Persada.

Raharjo M Dawam, 1993. Intelektual Intelegensia dan Perilaku Politik Bangsa, Bandung: Mizan 


\title{
Teori Nasakh Mansukh Dalam Penetapan Hukum Syariat Islam
}

\author{
Muhammad Husni dan Fathul Wahab \\ Institut Agama Islam Al-Qolam Malang \\ Email: husninanang73@gmail.com
}

\begin{abstract}
The existence of nasakh and mansukh in the determination of Islamic law is very important, because not always the law in one place is the same as the place and conditions in other places. It's just that in imposing nasakh and mansukh this is limited to the problems of shar'i law, while other than that it is not permissible such as the issue of aqidah or the points of worship and moral principles, such as justice, honesty, prohibition of shirk, killing, stealing and others etc .. Besides that, the determination of nasakh and mansukh is not permitted by using ijtihad or the opinions of the scholars, but it is indeed pure from Allah Almighty contained in the Qur'an. However, there are two opposing groups namely those who support the existence of nasakh and mansukh in the Qur'an and groups who reject the existence of nasakh and mansukh in the Qur'an. The middle way taken is to compromise the two opposing groups by reviewing the terms understanding nasakh and mansukh. With this compromise, it is hoped that there will be no more opposition regarding nasakh and mansukh. For this reason the scholars set ways to know nasakh and mansukh strictly. Despite the pros and cons of nasakh and mansukh. Nasakh and mansukh have provided great lessons for Muslims including the development of tasyri 'towards the level and the desire for goodness and convenience for Muslims.
\end{abstract}

\section{Keywords: Mansukh Nasakh, Islamic Sharia Law}

Abstrak: Keberadaan nasakh dan mansukh dalam penetapan hukum Islam sangat penting, karena tidak selamanya hukum dalam satu tempat sama dengan tempat dan kondisi di lain tempat. Hanya saja dalam memberlakukan nasakh dan mansukh ini terbatas pada masalah-masalah hukum syar'i, sementara selain itu tidak diperbolehkan seperti masalah aqidah atau pokok-pokok ibadah dan pokokpokok akhlaq, seperti keadilan, kejujuran, larangan syirik, membunuh, mencuri dan lain sebagainya.. Disamping itu penetapan nasakh dan mansukh tidak diperkenankan dengan menggunakan ijtihad atau pendapat dari para ulama, tetapi memang murni dari Allah swt yang terdapat di dalam Al Qur'an. Namun begitu, terdapat dua golongan yang berlawanan yaitu golongan yang mendukung adanya nasakh dan mansukh di dalam Al Qur'an dan golongan yang menolak adanya nasakh dan mansukh dalam Al Qur'an. Jalan tengah yang diambil adalah dengan jalan mengkompromikan kedua golongan yang bersebrangan dengan meninjau kembali istilah pengertian nasakh dan mansukh. Dengan adanya kompromi ini diharapkan tidak ada lagi pertentangan mengenai nasakh dan mansukh. Karena itulah para ulama menetapkan cara-cara untuk mengetahui 
nasakh dan mansukh secara ketat. Meskipun terjadi pro kontra terhadap nasakh dan mansukh. Nasakh dan mansukh telah memberikan hikmah yang besar bagi umat Islam diantaranya adalah Perkembangan tasyri` menuju tingkat dan menghendaki kebaikan dan kemudahan bagi umat Islam.

Kata Kunci: Nasakh Mansukh, Hukum Syariat Islam

Al Qur'an merupan sumber hukum utama dalam Islam. Sebagai sumber utama Al Qur'an bersifat baku dan universal artinya keberadaan Al Qur'an tetap orsinil sepanjang masa dan tidak mengalami perubahan sedikitpun baik dari segi bahasa maupun dari segi makna. Al Qur'an selalu up to date terhadap perkembangan zaman, ini bukan berarti Al Qur'an menyesuaikan diri dengan perkembangan zaman, akan tetapi Al Qur'an menjadi barometer bagi perkembangan zaman yang ditandai dengan kemajuan sains dan teknologi. Perkembangan sains dan teknologi sebagai puncak kebudayaan manusia harus menyelaraskan diri dengan $\mathrm{Al}$ Qur'an sehingga memiliki manfaat besar bagi kehidupan manusia. Kebudayaan yang menyelaraskan diri dengan Al Qur'an maka kebudayaan tersebut akan mengandung nilai-nilai kemanusian yang tinggi. Sedangkan Al Qur'an bersifat universal artinya bahwa syariat yang ditetapkan Al Qur'an berlaku untuk seluruh manusia yang tidak tersekat antara waktu dan ruang. Namun demikian hukumhukum Al Qur'an kebanyakan masih bersifat mujmal yang membutuhkan interpretasi dari para ulama. Meskipun interpretasi yang dilakukan oleh ulama tersebut terkadang terjadi perbedaan pandangan antara satu dengan yang lainnya. Perbedaan pandangan adalah rahmat, yang menurut Imam Taufiq, menunjukkan beragamnya cara pandang manusia sebagai makhluk yang berakal, memahami simbul, intelek, berilmu pengetahuan dan normatif. (Imam Taufiq, 2001, p.135) Sebagai hukum utama dalam Islam, kajian terhadap Al Qur'an terus dilakukan oleh para ulama. Karena Al Qur'an tidak hanya sumber hukum tetapi juga sumber ilmu pengetahuan karena apabila semakin dikaji dan digali maka semakin dalam arti Al Qur'an itu sendiri. Kajian tehadap Al Qur'an tidak hanya terbatas pada masalahmasalah hubungan ayat satu dengan ayat lain, tempat diturunkannya ayatayat tersebut, tetapi juga ayat-ayat yang berkaitan dengan printah dan larangan yang di dalamnya mengandung nasakh dan mansukh. Keberadaan nasakh dan mansukh itu sendiri telah menyebabkan terjadi perbedaan pandangan di kalangan ulama. Ada golongan ulama yang menerima nasakh dan mansukh itu sebagai dalam pemberlakuan hukum syariat. Ada pula golongan ulama yang menolok nasakh dan mansukh

$$
\text { Nasakh dan mansukh }
$$

merupakan issu sentral dalam pembahasan makalah ini, karena 
memahami Al Qur'an tidak terlepas dari permasalahan nasakh dan mansukh apalagi menyangkut permasalahan dalam menetapkan hukum.

\section{Pengertian}

Secara etimologis, kata naskh yang bentuk isim failnya "nasikh" dan isim maf 'ulnya "mansukh", mempunyai arti yang beragam, antara lain : menghilangkan, menghapuskan, membatalkan. Yang berarti membatalkan atau memindah dari satu wadah ke wadah yang lain. Atau juga berarti penukilan dan penyalinan, (Quraish Shihab, 1994, p.143) penghapusan/pembatalan (alizalah atau al-ibthal), pemindahan (al-naql), pengubahan/penggantian (al-ibdal), dan pengalihan (al-tahwil atau al-intiqal). ${ }^{5}$ Berkaitan dengan pengertian tersebut, maka nasikh (isim fa il) diartikan sesuatu yang membatalkan, menghapus, memindahkan, dan memalingkan. Sedangkan mansukh (isim maful) adalah sesuatu yang dibatalkan, dihapus, dipindahkan, diganti, dan dipalingkan. Terdapat perbedaan pendapat antara ulama mutaqaddimin dan mutaakhirin dalam mendefinisikan nasakh secara terminologis. Perbedaan pendapat tersebut bersumber pada banyaknya pengertian nasakh secara etimologi sebagaimana dijelaskan di atas. Cakupan makna yang ditetapkan ulama mutaqoddimin di antaranya: 1) Pembatalan hukum yang ditetapkan sebelumnya dengan hukum yang ditetapkan kemudian; 2) Pengecualian/pengkhususan hukum bersifat `am/umum oleh hukum yang lebih khusus yang datang setelahnya; 3) Bayan atau penjelasan yang datang kemudian terhadap hukum yang bersifat samar; 4) Penetapan syarat terhadap hukum terdahulu yang belum bersyarat (Moh. Nor Ichwan, p.108)

Di samping itu ada yang berpendapat bahwa istilah tersebut berarti pembatalan ketetapan hukum yang ditetapkan pada suatu kondisi tertentu oleh ketetapan lain yang berbeda akibat munculnya kondisi lain. Misalnya perintah agar kaum muslimin pada periode Mekkah bersabar karena lemah telah dinasakh oleh adanya perintah berperang pada periode Madinah karena kondisi mereka sudah kuat. Bahkan ketetapan hukum Islam yang membatalkan hukum yang berlaku pada masa sebelum Islam termasuk dalam pengertian nasakh (Dewan Redaksi Enskopedi Islam, 1997, p.16) Sementara menurut ulama mutaakhirin, nasakh adalah dalil yang datang kemudian, berfungsi untuk menggugurkan dan menghilangkan hukum yang pertama (Quraish Shihab, 2004, p.143) Dengan demikian ulama mutaakhirin mempersempit pengertian yang luas itu. Menurut mereka, nasakh adalah ketentuan hukum yang datang kemudian untuk membatalkan masa berlakunya hukum terdahulu. Artinya ketetapan hukum yang terdahulu tidak berlaku lagi dengan adanya ketetapan hukum yang baru (Dewan Redaksi Enskopedi Islam, p.16) Atas dasar itu, dalil yang datang kemudian disebut nasakh (yang menghapus). Sedangkan hukum yang pertama disebut mansukh (yang terhapus). Sementara itu, penghapusan hukumnya disebut nasakh (Kahar Mansykur, 2002, p.135) Sementara itu, menurut az- 
Zarqani, sebagaimana dinukil Moh. Nur Ichwan, yang dimaksud dengan terminologi "menghapuskan" dalam definisi tersebut adalah terputusnya hubungan hukum yang dihapus dari seorang mukallaf dan bukan terhapusnya subtansi hukum itu sendiri (Moh. Nor Ichwan, 2002, p.108) Definisi diatas apabila dijelaskan lagi, dapat kita tarik beberapa butiran-butiran makna yang tersirat, yakni: Dipastikan terjadi naskh apabila ada dua hal, yaitu nasikh dan mensukh. Nasikh harus turun belakangan dari mansukh, Menilai suatu ayat sebagai pe-naskh dan yang lain di-naskh-kan, apabila ayat-ayat yang kontradiktif itu tidak dapat dikompromikan dan diamalkan secara bersama. ${ }^{3}$ Sedangkan syarat kontradiksi; adanya persamaan subjek, objek, waktu, syarat, dan lain-lain. ${ }^{4}$ Menurut al Qaththan, nasakh ialah mengangkat (menghapus) hukum syara' dengan dalil hukum syara' lain. Kata "hukum" di sini, menunjukkan bahwa prinsip "segala sesuatu hukum asalnya boleh". Kata-kata dengan dalil hukum syara"” mengecualikan pengangkatan (penghapusan)hukum disebabkan kematian atau gila, penghapusan dengan ijma' atau qiyas. (Manna Khalil al-Qattan, 2001, p.285)

Kata nasikh (yang menghapus) maksud Allah seperti firman-Nya dalam surat Al-Baqarah ayat 106 "Dan tidaklah Kami menghapus suatu ayat....". kata itu juga digunakan untuk ayat atau sesuatu yang dengannya nasakh dapat diketahui dan digunakan pula untuk hukum menghapuskan hukum yang lain. Mansukh adalah hukum yang diangkat atau yang dihapus. (Manna
Khalil al-Qattan, 2001, p.286) Perlu dipahami bahwa terjadinya nasikh mansukh itu bukan berarti dalam alQur'an maupun al-Sunnah terdapat kontradiksi, tetapi menunjukkan fleksibilitas ajaran Islam, sehingga bisa disesuaikan dengan situasi dan kondisi sosiokultural penerima ajaran. Oleh sebab itu para ulama ushul menetapkan syarat kemungkinan terjadi nasikh dan mansukh, yaitu :Nasikh harus terpisah dari mansukh, Nasikh harus lebih kuat atau sama kekuatannya dengan mansukh, Nasikh harus berupa dalil-dalil syara', Mansukh tidak dibatasi dengan waktu, Mansukh harus berupa hukum syara', Nasikh wurudnya kemudian setelah mansukh',Disamping itu perlu diketahui bahwa ada Nash-Nash yang sudah pasti yang tidak mungkin dibatalkan, yaitu :

1. Nash yang berisi pokok ajaran, baik berupa aqidah atau pokok-pokok ibadah dan pokok-pokok akhlaq, seperti keadilan, kejujuran, larangan syirik, membunuh, mencuri dan lain sebagainya.

2. Nash yang berisi hukum abadi atau selamanya berdasarkan pernyataan Nash itu sendiri

3. Nash yang berisi pemberitaan satu kejadian baik yang sudah lewat atau yang akan datang (Abdul Wahhab Khalaf, 1968, p.226 - 227)

\section{Syarat-Syarat Mansukh}

Nasikh

Menurut al Qaththan dalam nasakh diperlukan syarat-syarat ; (1) 
Hukum yang dimansukh adalah hukum syara' (2) Dalil penghapusan hukum tersebut adalah khitab syar'i yang datang kemudian dari khithab yang hukumnya dimansukh. (3)Khitab yang dihapus atau diangkat hukumnya tidak terikat (dibatasi)dengan waktu tertentu. Sebab jika tidak demikian maka hukum akan berakhir dengan berakhirnya waktu tersebut. Dan yang demikian itu tidak dinamakan dengan nasakh (Manna Khalil alQattan, 2001, p.285) Sedangkan menurut Abu Anwar memberikan batasan beberapa syarat yang diperlukan dalam nasakh, yaitu : Hukum yang mansukh adalah hukum syara`. Nasakh hanya terjadi pada perintah dan larangan. Nasakh tidak terdapat dalam akhlak, ibadah, akidah, dan juga janji dan ancaman Allah.Dalil yang dipergunakan untuk penghapusan hukum tersebut adalah kitab syar`i yang datang kemudian. Dalil yang mansukh hukumnya tidak terikat atau dibatasi oleh waktu tertentu. Sebab, jika demikian hukum akan berakhir dengan waktu tersebut (Abu Anwar, 2009, p.52) Sebagian ulama ada yang memperluas syaratsyarat terjadi nasakh, yaitu: a.Hukum yang terkandung pada nasikh bertentangan dengan hukum pada mansukh.Yang mansukh harus lebih awal dari Nasikh. Hukum yang di-nasakh mesti hal-hal yang menyangkut dengan perintah, larangan, dan hukuman. Hukum yang di-nasakh tidak terbatas waktu tertentu, mesti berlaku sepanjang waktu. Hukum yang terkandung dalam mansukh telah ditetapkan sebelum munculnya nasikh. Status nash nasikh mesti sama dengan nash mansukh. Maka nash yang zhanni tidak bisa menasakh-kan yang qath'i (Kadar M.Yusuf, 2010117) Nasakh hanya terjadi pada perintah (amr) dan larangan (nahy), baik yang diungkapkan dengan tegas dan jelas maupun yang diungkapkan dengan kalimat berita yang bermaksud perintah atau larangan (khabar bi ma'na al amr aw al nahy), selama tidak berhubungan dengan akidah, zat Allah dan sifat-sifat Allah, kitabkitab Allah, para Rasul, hari kiamat, dan juga tidak terkait dengan etika atau akhlak atau dengan pokokpokok ibadah dan muamalat. (Manna Khalil al-Qattan, p.287) Quraish Shihab, menambahkan lagi syarat nasakh, bahwa nasakh baru dilakukan bila : 1) Terdapat dua ayat hukum yang saling bertolak belakang, serta tidak dapat lagi dikompromikan; 2) Harus diketahui secara meyakinkan urutan turunnya ayat-ayat tersebut. Yang lebih dahulu dikatakan mansukh, dan yang datang kemudian disebut nasakh (Moh. Nor Ichwan, p.146)

Beberapa

penjelasan mengenai pengertian dan syarat nasakh di atas, dapat disimpulkan Nasakh mempunyai empat rukun yaitu : 1) Nasakh, yaitu proses revisi atau penggantian hukum; 2) Nasakh, yaitu hukum pengganti, dalam hal ini Allah SWT, yang berhak secara mutlak untuk merevisi atau mengganti hukum tersebut; 3) Mansukh, yaitu hukum yang direvisi; dan 4) Mansukh `anhu, yaitu orang yang dikenai hukum atau mukalla (Ishom Elsaha dan Saiful Hadi, 2005, p.555)

\section{Pedoman Nasikh Mansukh}

Pengetahuan tentang nasakh dan mansukh mempunyai fungsi dan 
mafaat besar bagi para ulama, terutama para fuqaha, mufassir dan ahli ushul fikih, agar pengetahuan tentang hukum tidak menjadi kabur. Oleh karena itu, terdapat banyat atsar yang mendorong agar mengetahui masalah ini. Dari Ibnu Abbas, bahwa ia berkata tentang firman Allah ,'Dan barang siapa yang diberi hikmah, sesungguhnya ia telah diberi kebajikan yang banyak." (QS. AlBaqarah :269),"yang dimaksud ialah (yang diberi ilmu tentang nasikh dan mansukh, mutasyabihah, muqaddam dan mu'akharnya serta haram dan halalnya (Manna Khalil al-Qattan, p.288) Untuk mengetahui nasikh dan mansukh ada beberapa cara berikut: Ada keterangan tegas atau pentransimisian yang jelas dari Nabi S.A.W, Konsensus (ijma') umat bahwa ayat ini nasikh dan ayat itu mansukh.Mengetahui mana yang lebih dahulu dan mana yang belakangan berdasarkan histori. Histori ayat dapat diketahui dari keterangan sahabat, yang bukan ijtihad sahabat itu sendiri. Misalkan sahabat itu mengatakan: "Ayat ini turun pada tanggal, bulan atau tahun sekian, sedangkan ayat ini turun pada tanggal, bulan atau tahun sekian, jadi ayat ini lebih kemudian dari ayat itu". Nasikh tidak dapat ditetapkan berdasarkan ijtihad, pendapat mufassir atau kontradiksi dalil-dalil secara lahiriyah atau terlambatnya keislaman salah seorang dari dua perawi. (Manna Khalil al-Qattan, p.288) Ketiga persyaratan itu merupakan faktor yang sangat menentukan adanya nasakh dan mansukh dalam al-Quran. Jadi berdasarkan penjelasan di atas dapat dipahami bahwa nasakh mansukh hanya terjadi dalam lapangan hukum, dan tidak termasuk penghapusan yang bersifat asal (pokok). Sedangkan kedudukan nasakh merupakan salah satu bentuk interpretasi hukum dalam upaya menghadapi ayat atau hadits yang tampak kontradiktif selain dari tarjih atau taksis dalam disiplin ilmu ushul Fiqh. Kuncinya terletak pada soal historis yang menyangkut kedua ketentuan hukum tersebut. Faktor azbabun nuzul ada dalam tingkat ini untuk mengetahui mana ayat yang datang terdahulu dan ayat yang datang kemudian. (Hasan Asyari Ulama I, 2016, p.13) Menurut Yusuf Qardhawi, setidaknya ada tiga kecenderungan dalam masalah nasakh, yaitu : 1) Ada yang meluaskan diri dalam mengklaimadanya nasakh dalam alQuran dan berpendapat bahwa sekian dalam surat sekian dinasakh, sementara tidak ada dalil yang kuat terhadap pe-nasakhan itu; 2) Sebagai antithesis dari mereka, ada yang mengingkari sama sekali adanya nasakh dalam al-Quran; dan 3) Ada pendapat pertengahan yang mengakui adanya nasakh, jika dalil yang sahih dan jelas, yang meyakinkan akal dan menenangkan hati (Yusuf Qardhawi, 1999, p.467)

\section{Pandangan Para Ulama Tentang Nasikh Mansukh}

Pembahasan tentang nasakh dan mansukh yang muncul dalam kajian ilmu tafsir merupakan masalah yang mengandung perdebatan di kalangan para ulama. Kontroversi yang timbul bertolak dari bagaimana memahami dan menghadapi ayat-ayat Al Qur'an yang pada lahirnya kelihatan saling berlawanan. Segolongan ulama 
berpendapat bahwa ada ayat-ayat yang bertentangan dan tidak bisa dikompromikan dan dengan demikian ada nasakh dalam Al Qur'an. Sebaliknya, segolongan ulama lainnya berpendapat bahwa ayat-ayat yang dikatakan tampak bertentangan bisa dikompromikan dan dengan demikian tidak ada nasakh dalam Al Qur'an. (Dewan Redaksi Enskopedi Islam, p.17)

a. kelompok ulama yang mendukung nasakh dan mansukh

Salah satu ayat yang menjadi basis pembangunan teori nasakh adalah firman Allah dalam surat al-Baqarah ayat 106:

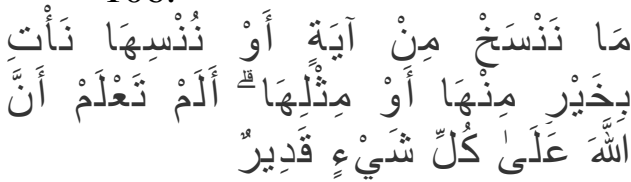

Ayat mana saja yang Kami nasakhkan, atau Kami jadikan (manusia) lupa kepadanya, Kami datangkan yang lebih baik daripadanya atau yang sebanding dengannya. Tidakkah kamu mengetahui bahwa sesungguhnya Allah Maha Kuasa atas segala sesuat Ayat tersebut dijadikan dasar naqli bagi mayoritas ulama yang mendukung adanya nasakh dalam al-Quran. Mayoritas ulama tanpa keraguan menetapkan ayat-ayat yang termasuk nasakh dan mansukh tetap berlaku, akan tetapi segi hukum yang berlaku menyeluruh sampai waktu tertentu tidak dapat dibatalkan kecuali oleh syara'. Jadi menurut mereka, nasikh mansukh bisa diterima oleh akal dan telah terjadi dalam hukum syara' sesuai dalil di atas. Selain dalil naqli di atas, jumhur ulama pendukung nasakh juga mendasarkan dalil naqli. Mereka berpandangan perbuatan Allah itu mutlak, tidak tergantung pada alasan dan tujuan. Ia boleh saja memerintahkan sesuatu pada suatu waktu dan melarangnya pada waktu yang lain. Ini karena, Allah lebih mengetahui kepentingan hambanya (Manna Khalil al-Qattan, p.331) Pendapat lain yang mendasari mayoritas ulama tentang teori nasakh adalah penetapan perintah-perintah tertentu kepada kaum muslimin di dalam al-Quran yang menurut Rosihan Anwar, ada yang bersifat sementara dan ketika keadaan berubah perintah tersebut dihapus dan diganti dengan perintah baru lainnya. Namun, karena perintahperintah itu kalam Allah, harus dibaca sebagai bagian dari alQuran. (Rosihan Anwar, 2007, p.163) Persoalan nasakh bagi kelompok pendukungnya merupakan salah satu cara menyelesaikan beberapa dalil tersebut. Apabila tidak bisa dikompromikan, salah satunya dinasakh atau dibatalkan. Di samping itu, mereka berpendapat bahwa dalam alQuran secara implisit memang mengandung konsep nasakh. Oleh karen itu jika seseorang ingin menafsirkan al-Quran, menurut M. Abu Zahrah, harus terlebih dahulu mengetahui tentang nasikh dan mansukh (Muhammad Abu Zahrah, 
2008, p.120) Menurut kelompok ini keberadaan nasakh dalam al-Quran selain memiliki dasar dari al-Quran, secara praktis juga nyata dalam sejarah Islam, dan nasakh disebut secara eksplisit di dalam al-Quran. Rachmat Syafe'i memberikan batasan terhadap ayat yang dinasakh, yaitu : (1) ayat al-Quran yang konsekwensi hukumnya saling bertolak belakang dan tidak dapat dikompromikan, (2) harus diketahui secara meyakinkan urutan turunnya ayat-ayat tersebut, yang lebih dahulu ditetapkan sebagai mansukh dan yang datang kemudian sebagai nasikh (Rachmat Syafe'i, 2006, p.94) Jumhur ulama, antara lain Imam Syafi'i mengakui adanya nasakh dalam Al Qur'an. Menurut mereka, ayat yang dinasakh adalah ayat Al Qur'an yang mengandung ketentuanketentuan hukum.disamping alasan nash-nash itu, menurut mereka ada ayat-ayat yang bertentangan dan tidak bisa dikompromikan. (Dewan Redaksi Enskopedi Islam, p.16)

Munawir Sjadzali juga sependapat dengan kelompok yang menyatakan adanya nasakh, sehingga ia menggunakan metode klasik yang disebut dengan nasakh tersebut. Namun dalam praktiknya, Munawir Sadjali menggunakannya dengan cara yang berbeda dengan ulama klasik, sehingga menghasilkan pemahaman yang radikal dan memberikan peran yang luas kepada akal untuk melakukan reinterpretasi terhadap hukum atau petunjuk yang telah diberikan dalam ayat-ayat alQuran dan hadis nabi Muhammad saw. (Munawir Sjadzali , 1997, p.47) Sayyid Quthb dalam tafsirnya "Tafsir fi Zhilal al-Qur'an" berpendapat bahwa ayat 106 dari surat al-Baqarah itu diturunkan sebagai sanggahan terhadap tuduhan orang-orang yahudi bahwa Nabi tidak konsisten, baik mengenai kepindahan kiblat dari masjid al-Aqsha ke Masjid al-Haram, maupun perubahan petunjuk, hukum dan perintah yang terjadi akibat pertumbuhan masyarakat Islam, dan situasi serta kondisi mereka yang terus berkembang (Sayyid Quthb, p.101-102) Berdasarkan paparan di atas, dapat dipahami bahwa nasakh (pergeseran atau pembatalan hukum/petunjuk) itu dapat terjadi tidak hanya pada zaman nabi Muhammad saw. tetapi juga sepeninggal beliau kalau memang kondisi dan situasinya telah berubah. Di samping itu akal budi manusia juga dapat berperan sebagai alat yang dapat menasakh wahyu atau membatalkan/menggeser hukum baik yang termaktub dalam ayat-ayat al-Quran maupun Hadis Nabi saw. selama hal tersebut berkaitan dengan masalah mu'amalah (kemasyarakatan). Dengan demikian, bukan berarti alQuran dan Hadits yang diubah, 
bukan pula syari'at yang diubah, tetapi pengetrapannya yang dapat diubah (Munawir Sjadzali, 1985, p.87) Pandangan Munawir Sadzali, yang menyatakan bahwa nasakh dapat terjadi sepeninggal nabi Muhammad saw., ini jelas-jelas bertentangan dengan ulama yang berpegang pada pandangan klasik yang menyatakan bahwa naskh hanya terjadi pada masa nabi Muhammad saw. atau masa tasyri'. Demikian juga pendapatnya yang membolehkan akal budi (rasio) manusia sebagai alat yang dapat menaskh wahyu Allah bertentangan dengan pendapat umum Ahmad Azhar Basyir, salah seorang tokoh Muhammadiyah misalnya mengatakan bahwa yang berhak menasakh hukumhukum Allah hanya Allah sendiri. Selain Allah tidak berhak menasakh hukumhukum Allah. Setelah al-Quran selesai diwahyukan, nasikh mansukh sudah berhenti. Semua pernyataan fuqaha' dan mufassirin tentang kemungkinan terjadinya nasakh, tertuju pada kurun waktu semasa al-Quran belum selesai diwahyukan. Oleh karenanya jalan nasakh tidak dapat dipergunakan untuk membahas kemungkinan reaktualisasi ajaran Islam, setelah al-Quran diturunkan empat belas abad yang lalu. (Ahmad Azhar Basyir, p.56) Pernyataan senada juga dikemukakan oleh Ali Yafie salah seorang tokoh Nahdlatul Ulama yang menyatakan bahwa perubahan hukumhukum (taghayyur al-ahkam) melalui jalur nasakh terjadi pada tingkat syariah (al-Quran dan Sunnah) saja. Dengan berakhirnya periode tasyri (dengan wafatnya penerima wahyu yaitu Rasulullah saw.) maka perubahan-perubahan hukum Islam melalui jalur nasakh, sudah berakhir juga. Maka merujuk kepada naskh dalam rangka upaya revision of the law dalam hukum Islam tidak pada tempatnya. (Ali Yafie, 1998, p.100) Berdasarkan pernyataan di atas, tampaknya M. Quraish Shihab memperbolehkan adanya pergantian hukum (nasakh) oleh manusia terhadap kasus yang dihadapinya dengan beralih pada ayat hukum yang dianggap cocok sesuai kasus yang dihadapinya. Semua ayat al-Quran tetap berlaku, tidak ada kontradiksi. Yang ada hanya pergantian hukum bagi masyarakat/orang tertentu, karena kondisi yang berbeda. Ayat hukum yang tidak lagi berlaku baginya, tetapi dapat berlaku bagi orang lain yang kondisinya sama dengan kondisi mereka semula (M. Quraish Shihab, p.149-150)

b. Ulama yang menolak nasakh mansukh

Golongan ulama yang menolak adanya nasakh dalam al-Quran berusaha mengkompromikan ayat-ayat yang kelihatan 
bertentangan sehingga tidak perlu dinasakh. Kelompok penolak yang dipelopori oleh Abu Muslim al-Isfahani, menyatakan bahwa dalam alQuran tidak terdapat nasakh. Jika mengakui adanya nasakh berarti mengakui adanya kebatilan dalam al-QuranAbu Muslim al-Isfahani mendasarkan argumentasinya pada al-Quran surat Fushilat ayat 42

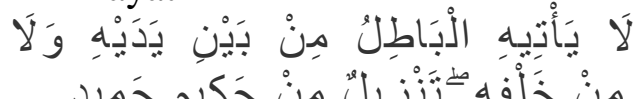

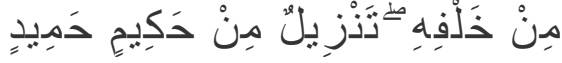
Yang tidak datang kepadanya (Al Quran) kebatilan baik dari depan maupun dari belakangnya, yang diturunkan dari Rabb Yang Maha Bijaksana lagi Maha Terpuji.

Hukum-hukum yang dibawa al-Quran bersifat abadi dan universal. Jadi tidak layak kalau di dalam al-Quran terdapat nasakh. Lebih lanjut abu Muslim al-Isfahani, sebagai mana dikutip Amir Syarifuddin, mengemukakan argumentasi sebagai berikut : Suatu hukum yang ditetapkan oleh Allah SWT adalah karena adanya maslahat atau mafsadat pada sesuatu yang dikenai hukum itu. Sesuatu yang mengandung maslahat tidak mungkin beralih menjadi mafsadat. Kalam itu bersifat qadim, dalam arti telah ada sejak dahulu (azali) sesuatu yang bersifat qadim tidak mungkin dicabut. (Amir Syarifuffin, 2007, p.229) Sehingga jelas, al-Isfahani tidak setuju adanya nasakh. AlIsfahani setuju menginterpretasikan ayat yang secara zhahir terjadi kontradiksi dengan jalan takhsis (pengkhususan), untuk menghindari adanya nasakh atau pembatalan, al-Isfahani berpendapat bahwa pembatalan hukum dari Allah mengakibatkan kemustahilanNya, yaitu : Ketidaktahuan, sehingga perlu mengganti atau membatalkan satu hukum dengan hukum lainnya. b. Jika itu dilakukan Allah, berarti Dia melakukan kesia-siaan dan permainan belaka. (M. Quraish Shihab, p.144) Berbeda dengan al-Isfahani yang cenderung kepada takhsis, Muhammad Abduh menolak adanya nasakh, dalam arti pembatalan, tetapi menyetujui adanya tabdil (dalam pengertian: pengalihan, pemindahan ayat hukum dengan ayat hukum lainnya). Dalam arti bahwa semua ayat al-Quran tetap berlaku, tidak ada kontradiksi. Yang ada hanya pengalihan hukum bagi masyarakat atau orang tertentu, karena kondisi yang berbeda. (Rachmat Syafe'i, 2006, p.88)

Dengan demikian ayat hukum yang tidak berlaku baginya, tetap berlaku bagi orang lain yang kondisinya sama dengan kondisi mereka. Dalam perspektif hikmah, pemahaman semacam ini menurut Quraish Shihab akan sangat membantu dakwah Islamiyah, sehingga ayat-ayat hukum yang bertahap dapat dijalankan oleh mereka yang kondisinya sama dengan kondisi umat Islam pada awal masa Islam. (M. Quraish 
Shihab, p.148) Kendatipun uraian diatas telah dipaparkan, namun terdapat pendapat tentang nasakh, yang dalam masalah ini terbagi pada beberapa golongan: Orang yahudi, menurut mereka naskh tidak bisa diakui, karna naskh mengandung konsep bada', sedangkan bada' adalah muncul setelah tersembunyi. Mereka berpendapat naskh adakalanya tanpa hikmah, dan itu mustahil bagi Allah. Dan adakalanya karna suatu hikmah, tetapi hikmah itu muncul setelah sembunyi, yakni sebelumnya tidak nampak oleh Allah Kalangan Syi'ah Rafidhah, mereka sangat berlebihan dan bahkan memperluas ruang lingkup dalam menetapkan (al Qaththan, p.289-2991) Abu Muslim al Ashfahani, menurutnya naskh secara akal dapat saja terjadi, tetapi menurut syara' naskh tidak bisa terjadi, Jumhur ulama, naskh adalah suatu yang dapat diterima secara akal dan telah terjadi pula dalam hukumhukum syara', berdasarkan dalil-dalil: 1)Perbuatan Allah tidak bergantung pada alasan dan tujuan. Allah boleh saja memerintahkan sesuatu pada satu waktu dan melarangnya pada waktu lain. 2)Nash-nash al Qur'an dan Sunnah menunjuk pada kebolehan nasakh dan terjadinya

Sebenarnya para ahli al Qur'an mengambil sikap yang berbeda-beda terhadap masalah ini. Pertama menolak teori nasakh dengan alasan tidak ada pertentangan antara ketentuan satu ayat dengan ayat lainnya dalam al Qur'an yang tidak dapat diselesaikan dengan cara dikompromikan dengan cara al jami' atau dengan takhsisi. kedua, memodifikasi teori nasakh dalam arti penghapusan dan pembatalan sebab nasakh merupakan penggantian satu syari'at kepada syari'at lain yang lebih sesuai sehingga mudah diterima. Penggantian hukum dengan hukum baru karena disebabkan oleh faktor kondisi dan situasiasi yang memang berbeda. Ketiga, melakukan dekonstruksi teori nasakh. Sikap ini merupakan pengakuan adanya nasakh mansukh dalam al Qur'an. Sikap ini didasarkan pada pemikiran bahwa nasakh merupakan suatu kebenaran historis yang sudah saatnya untuk ditinggalkan. Ditinggalkan bukan berarti pengingkaran tetapi penghapusan model teori nasakh itulah yang tidak dapat diterima untuk situasi sekarang ini. (Aksin Wijaya, 2009, p.137) Menurut Muhammad Thaha, nasakh bukan penghapusan hukum, melainkan sebagai penundaan hukum sambil menunggu waktu yang tepat. Menurutnya syariat Islam merupakan syariat yang sempurna dan kesempurnaannya terletak pada kemampuannya untuk berkembang. Ia melingkupi potensi-potensi kehidupan masyarakat baik individu 
maupun sosial, dan ia mampu mengarahkan kehidupan tersebut ke dalam tahap-tahap kemajuan yang berlangsung terus-menerus. Kehidupan senantiasa berjalan menuju Allah dalam perjalanan kembalinya. Pertemuan dengan penciptanya merupakan keniscayaan yang telah ditetapkan oleh tahapan syariat yaitu syariah, tariqat dan haqiqat. (Aksin Wijaya, 2009, p.138) Menurut Thaha, perkembangan syariat Islam sebenarnya hanyalah perpindahan dari satu ayat ke ayat lain, dari ayat yang sejalan dengan situasi masa abad VII, beralih kepada ayat yang sejalan atau dianggap lebih tepat untuk kondisi waktu sekarang. Oleh karena itu ketika ayat-ayat Madaniyah yang pada abad VII menasakh ayat-ayat Makkiyah dan telah menjalankan fungsinya tidak layak untuk situasi baru abad XX. Ayat-ayat yang layak untuk situasi sekarang adalah ayat-ayat Makkiyah yang berisi pesan Islam paripurna yang karena situasi dan kondisi ia belum bisa diterima masyarakat Makkah. (Aksin Wijaya, 2009, p.138) Diantara ulama yang menolak Nasakh dan Mansukh dalam Al Qur'an adalah Abu Muslim Asfahami, Imam Ar Razi, Muhammad Abduh, Rashid Redha, Dr. Taufiq Sidqy, Muhammad Khudhari Bek. Alasan penolakan mereka didasarkan pada Surat Al Baqarah ayat 106 ayat yang sama yang digunakan oleh pendukung Nasakh dan Mansukh dengan perbedaan penafsiran. Alasanalasan mereka adalah sebagai berikut : 1) Kandungan Surat Al Baqarah ayat 106 oleh kelompok pendukung Nasakh dan Mansukhdijadikan sebagai argument adanya nasakh dalam Al Qur'an, menurut mereka ditujukan kepada kaum Yahudi yang mengingkari Al Qur'an atau merujuk pada wahyu yang diturunkan sebelum Al Qur'an yang akhirnya digantikan oleh Al Qur'an. Artinya, hukumhukum yang terdapat dalam kitab-kitab suci sebelumnya diganti dengan yang lebih baik yaitu Al Qur'an. Menurut mereka, kalau Al Qur'an benar-benar datang dari Allah swt, maka pasti tidak akan berbeda dari isi kitab-kitab sebelumnya. Untuk itulah Allah menjawab bahwa Dia lebih tahu apa yang maslahat buat hamba-hamba-Nya untuk setiap zaman 2) Jika dalam Al Qur'an ada ayat yang mansukh berarti dalam Al Qur'an berbarti terdapat kesalahan dan saling berlawanan, padahal Al Qur'an sendiri menegaskan : "tidak datang kepada Al Qur'an kebatilan dari depannya maupun dari belakangnya.."(QS.41:42),3)

Rasulullah saw sendiri tidak pernah mengatakan adanya nasakh dalam Al Qur'an. Seandainya ada sudah tentu ia akan menjelaskannya 4) Hadishadis yang dikatakan oleh pendukung nasakh dinilai sebagai penasikh Al Qur'an 
bukanlah hadis mutawatir melainkan hadis ahad yang tidak mempunyai kualifikasi untuk menjadi hujjah dalam menetapkan hukum sesuatu, 5) Dikalangan pendukung nasakh sendiri tidak ada kesepakatan dalam menentukan jumlah ayat-ayat yang mansukh. (Dewan Redaksi Enskopedi Islam, p.18)

Jalan terbaik untuk mengkompromikan kedua kelompok tersebut yaitu dengan jalan meninjau kembali pengertian istilah nasakh yang dikemukakan oleh ulama. Untuk usaha ini, pemikiran Muhammad Abduh dalam menafsirkan ayat-ayat $\mathrm{Al}$ Qur'an dapat dijadikan sebagai titik tolah. Ia menolak adanya nasakh dalam pengertian "pembatalan", tetapi ia dapat menerima dalam pengertian at-tabdil (penggantian/pengalihan/pemin dahan ayat hukum di tempat ayat hukum yang lain). Dengan demikian pengertian istilah nasakh adalah pergantian atau pemindahan dari satu wadah ke wadah yang lain, dalam arti semua ayat Al Qur'an tetap berlaku, tidak ada kontradiktif dan yang dibatalkan. Hanya saja terjadi pergantian hukum bagi masyarakat/orang tertentu karena adanya kondisi yang berbeda. Namun demikian, ayat yang tidak berlaku bagi masyarakat dalam satu kondisi sama dengan kondisi mereka semula. Pemahaman demikian akan sangat membantu dalam pengembangan hukum Islam, sehingga ayat-ayat hukum

yang bertahap tetap diberlakukan oleh mereka yang kondisinya sama atau serupa dengan kondisi umat Islam pada awal perkembangan Islam. (Dewan Redaksi Enskopedi Islam, p.19)

Meskipun nasakh mansukh memiliki cakupan yang banyak. Terhadap hal yang demikian ini para ulama memiliki sikap yang berbedabeda : 1) Ada yang berlebihlebihan, sehingga ia memasukkan ke dalam kelompok nasakh sesuatu yang sebenarnya tidak termasuk di dalamnya, 2) Ada yang berhati-hati, dengan mendasarkan masalah nasakh ini hanya pada penukilan yang shahih semata. (Manna Khalil al-Qattan, p.299)

Sumber kekaburan tersebut bagi mereka yang berlebihlebihan, cukup banyak. Yang terpenting diantaranya ialah : Menganggap takhshish juga sebagai nasakh, Menganggap bayan (penjelasan) sebagai nasakh, Menganggap suatu ketentuan yang disyariatkan karena sesuatu sebab yang kemudian sebab itu hilang (dan secara otomatis ketentuan itu pun menjadi hilang) sebagai mansukh. Misalnya perintah bersabar dan tabah terhadap gangguan orang kafir pada masa awal da'wah ketika umat Islam masih lemah dan minoritas. Menurut mereka, perintah itu dihapuskan dengan ayat-ayat perang. Padahal sebenarnya yang pertama, 
yakni kewajiban bersabar dan tabah terhadap gangguan tetap berlaku di saat umat Islam dalam keadaan lemah dan minoritas. Sedang dalam keadaan mayoritas dan kuat, umat Islam wajib mempertahankan akidah melalui perang. Dan itulah hukum kedua yang berdiri sendiri, Menganggap tradisi jahiliyah atau syariat umat terdahulu yang dibatalkan Islam, sebagai nasakh. Misalnya, pembatasan jumlah istri dengan empat dan legalisasi hukum qishas dan diyat, sedang bagi bani Israil hanya berlaku hukum qishas saja, sebagaimana dikatakan Ibnu Abbas sebagaimana yang diriwayatkan oleh Al Bukhari. Hal ini bukanlah nasakh, melainkan pembatalan (alBara'ah Al-Ashliyah) (Manna Khalil al-Qattan, p.230)

\section{Bentuk Dan Macam-Macam Nasakh Dalam Al Qur'an}

Berdasarkan kejelasan dan cakupannya, nasakh dibagi menjadi :

a. Nasakh sharih yaitu ayat yang secara jelas menghapus hukum yang terdapat pada ayat terdahulu. Misalnya ayat tentang perang pada surata al anfal ayat 68

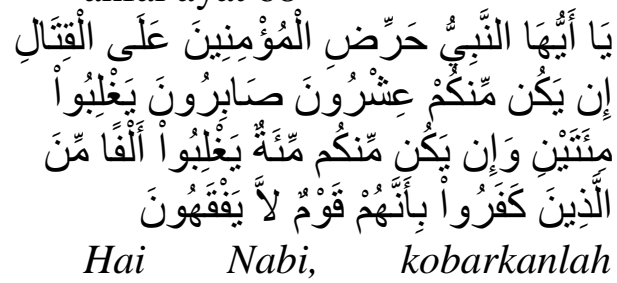
semangat para mu'min untuk berperang. Jika ada dua puluh orang yang sabar diantaramu, niscaya mereka akan dapat mengalahkan dua ratus orang musuh. Dan jika ada seratus orang yang sabar diantaramu, niscaya mereka akan dapat mengalahkan seribu dari pada orang kafir, disebabkan orangorang kafir itu kaum yang tidak mengert

Ayat ini menurut jumhur di nasakh oleh ayat yang mengharuskan satu orang mukmin melawan dua orang kafir pada ayat 66 surat yang sama

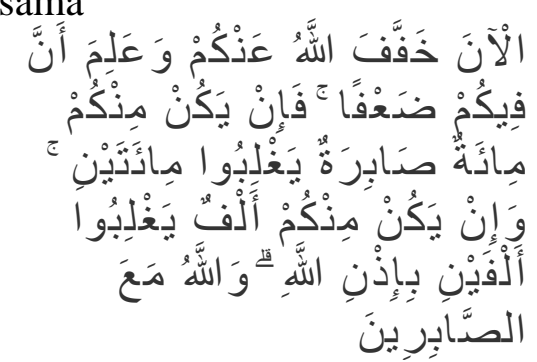

Sekarang Allah telah meringankan kepadamu dan dia telah mengetahui bahwa padamu ada kelemahan. Maka jika ada diantaramu seratus orang yang sabar, niscaya mereka akan dapat mengalahkan dua ratus orang kafir; dan jika diantaramu ada seribu orang (yang sabar), niscaya mereka akan dapat mengalahkan dua ribu orang, dengan seizin Allah. Dan Allah beserta orang-orang yang sabar.

b. Nasakh Dzimmi, yaitu jika terdapat dua nasakh yang saling bertentangan dan tidak dikompromikan dan keduanya turun untuk sebuah masalah yang sama, serta kedua-duanya diketahui waktu turunnya, ayat yang datang kemudian dihapus 
ayat yang terdahulu. Seperti surat al Baqarah ayat 180

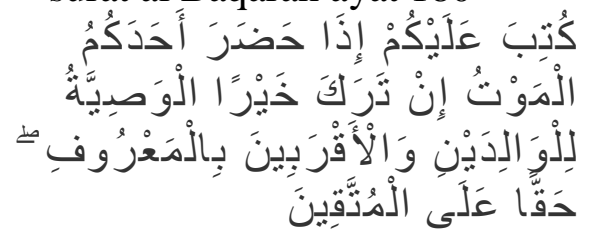

Diwajibkan atas kamu, apabila seorang di antara kamu kedatangan (tanda-tanda) maut, jika ia meninggalkan harta yang banyak, berwasiat untuk ibu-bapak dan karib kerabatnya secara ma'ruf, (ini adalah) kewajiban atas orangorang yang bertakwa.

Ayat ini dinasakh denga hadis yang berbunyi : la washiyyah li waris

c. Nasakh kully yaitu menghapus hukum yang sebelumnya secara keseluruhan. Contohnya ketentuan iddah empat bulan sepeuh hari pada surat al Baqarah 234 di nasakh oleh ketentuan iddah satu tahun pada ayat 240 pada surat yang sama

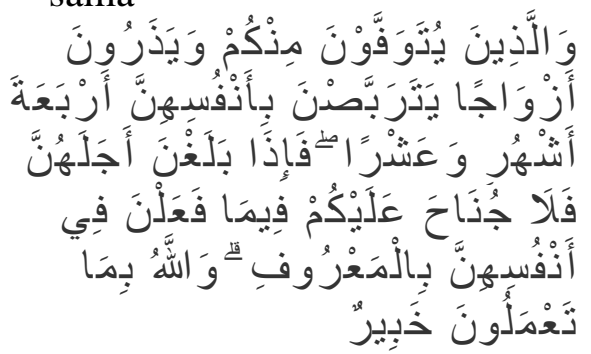

Orang-orang yang meninggal dunia di antaramu dengan meninggalkan isteri-isteri (hendaklah para isteri itu) menangguhkan dirinya (ber'iddah) empat bulan sepuluh hari. Kemudian apabila telah habis 'iddahnya, maka tiada dosa bagimu (para wali) membiarkan mereka berbuat terhadap diri mereka menurut yang patut. Allah mengetahui apa yang kamu perbuat.

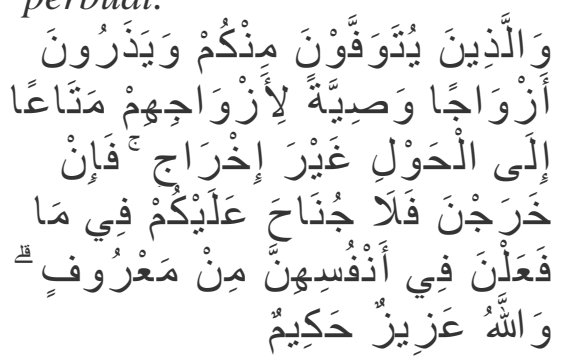

Dan orang-orang yang akan meninggal dunia di antara kamu dan meninggalkan isteri, hendaklah berwasiat untuk isteri-isterinya, (yaitu) diberi nafkah hingga setahun lamanya dan tidak disuruh pindah (dari rumahnya). Akan tetapi jika mereka pindah (sendiri), maka tidak ada dosa bagimu (wali atau waris dari yang meninggal) membiarkan mereka berbuat yang ma'ruf terhadap diri mereka. Dan Allah Maha Perkasa lagi Maha Bijaksana

d. Nasakh Juz'i yaitu menghapus hukum umum yang berlaku bagi semua individu dengan hukum yang hanya berlaku bagi sebagian individu atau menghapus hukum yang bersifat muthlaq . dengan hukum yang muqayyad contoh surat an nur ayat 4 dengan ayat 6 surat yang sama

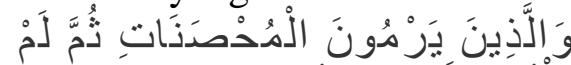

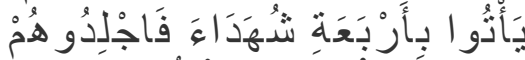

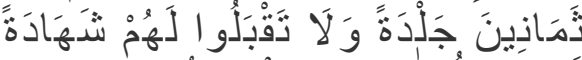

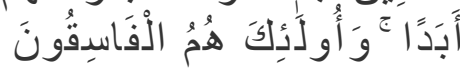

Dan orang-orang yang menuduh wanita-wanita yang baik-baik (berbuat zina) dan mereka tidak mendatangkan empat orang saksi, maka 
deralah mereka (yang menuduh itu) delapan puluh kali dera, dan janganlah kamu terima kesaksian mereka buat selama-lamanya. Dan mereka itulah orang-orang yang fasik Ayat tersebut di nasakh dengan ayat 6 pada surat yang sama

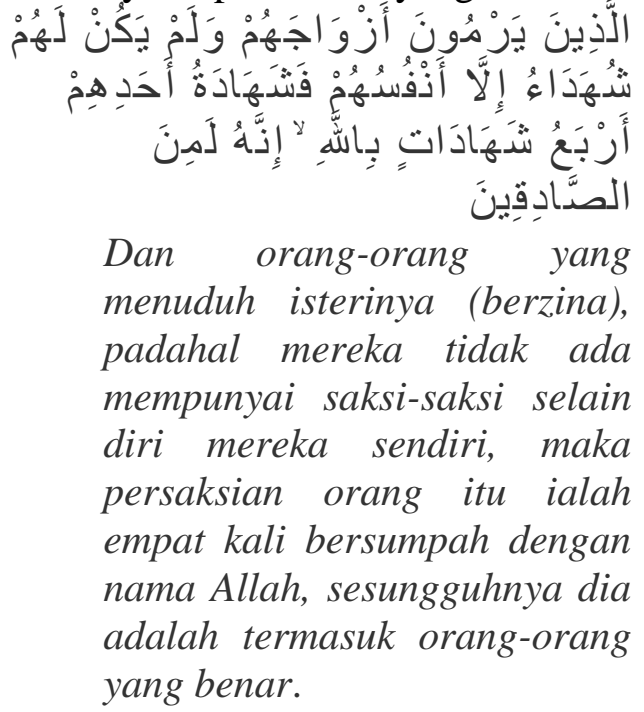

Dan orang-orang yang menuduh isterinya (berzina), padahal mereka tidak ada mempunyai saksi-saksi selain diri mereka sendiri, maka persaksian orang itu ialah empat kali bersumpah dengan nama Allah, sesungguhnya dia adalah termasuk orang-orang yang benar.

Dilihat dari segi bacaan dan hukumnya ulama membaginya menjadi tiga yaitu:

a. Penghapus terhadap hukum dan bacaan (tilawah) secara bersamaan. Ayat- ayat yang terbilang kategori ini tidak dibenarkan dibaca dan tidak dibenarkan diamalkan. Misalnya tentang hadis tentang saudara sesusuan sebanyak sepuluh isapan. Ketetapan ini kemudian dinasakh menjadi lima isapan

b. Penghapusan terhadap hukumnya saja sedangkan bacaannya tetap ada. Contohnya ajakan para penyembah berhala dari kalangan musyrikin kepada umat Islam untuk saling bergantian dalam beribadah, telah dihapus oleh ketentuan ayat qital (peperangan) tetapi bunyi teknya tetap ada

$$
\text { لَكَُمْ دِينُكُمْ وَلِّيَ دِينِ }
$$

Untukmu agamamu, dan

untukkulah, agamaku"

Contoh lainnya tentang sedekah dalam surat mujadilah ayat 12

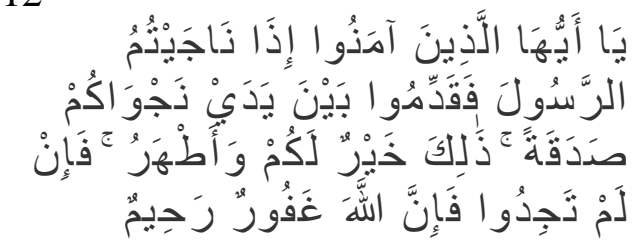

Hai orang-orang beriman, apabila kamu mengadakan pembicaraan khusus dengan Rasul hendaklah kamu mengeluarkan sedekah (kepada orang miskin) sebelum pembicaraan itu. Yang demikian itu lebih baik bagimu dan lebih bersih; jika kamu tidak memperoleh (yang akan disedekahkan) maka sesungguhnya Allah Maha Pengampun lagi Maha Penyayang.

Ayat ini dinasakh dengan ayat 13 surat yang sama

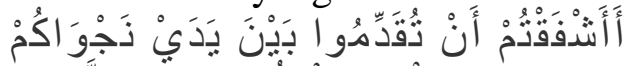

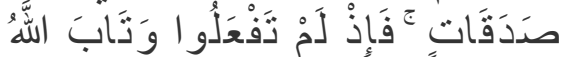

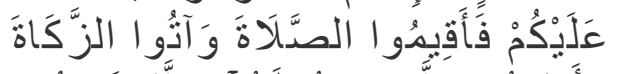

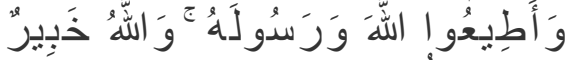

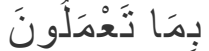

Apakah kamu takut akan (menjadi miskin) karena kamu memberikan sedekah sebelum mengadakan pembicaraan dengan Rasul? Maka jika kamu tiada memperbuatnya dan Allah telah memberi taubat kepadamu maka dirikanlah shalat, tunaikanlah zakat, taatlah kepada Allah dan Rasul-Nya; dan Allah Maha 
Mengetahui apa yang kamu kerjakan.2

c. Penghapusan terhadap bacaannya saja sedangkan hukumnya tetap berlaku

Adapun dari sisi otoritas mana yang berhak menghapus sebuah nasakh para ulama membagi nasakh ke dalam empat macam yaitu :

Nasakh al Qur'an dengan al Qur'an, Nasakh al Qur'an dengan sunnah. Bagi kalangan Hanafiyah nasakh semacam ini diperkenankan bila sunnahnya itu mutawatir atau masyhur. Tetapi pendapat ulama-ulama Hanafiyah ini ditentang oleh mayoritas ulama ushul fiqh. Bagi mereka apap pun jenis sunnah yang akan menghapus ketentuan-ketentuan al Qur'an tetap tidak diperkenankan Nasakh Sunnah dengan al Qur'an. Mayoritas ulama nasakh semacam ini diperkenankan, Nasakh sunnah dengan sunnah. Menurut al Qathtan, pada dasarnya ketentuan nasakh dalam ijma' dan qiyas tidak diperkenankan Persoalan lebih jauh dalam masalah nasikh-mansukh ini ialah soal nasikh-mansukh antara Al Qur'an dengan sunnah. Adanya nasikh mansukh antara satu ayat yang memat ketentuan hukum dalam Al Qur'an dengan lain ayat yang juga memuat ketentuan hukum dalam soal yang sama adalah satu hal yang tidak diperselisihkan lagi. Demikian pula adanya nasikhmansukh antara hadis yang memuat ketentuan hukum dalam soal yang sama merupakan satu hal yang tidak diperselisihkan lagi. Masalah yang menimbulkan perselisihan pendapat diantara para ulama ialah adanya nasikh mansukh silang antara $\mathrm{Al}$ Qur'an dengan sunnah. Jika disimak alasan masing-masing yang menjadi perbedaan pendapat ialah pandangan masing-masing tentang kedudukan hirarki Al Qur'an dan sunnah dalam syariat itu sendiri (Sukardi KD, 2002, p.173) Dalam kaitan hirarki Al Qur'an dan sunnah, ada semacam kesepakatan bahwa dalam nasikh-mansukh kedua unsurnya harus sama tingkatnya dan sama nilai dan sifatnya. Jalan pikiran sepeerti ini terdapat juga di kalangan ahli hukum bahwa suatu peraturan hukum tidak dapat dicabut dengan peraturan hukum lainnya yang lebih rendah tingkatannya. Demikian juga lembaga yang mengeluarkanperaturan hukum menjadi factor pertimbangan. Berdasarkan pemikiran ini, ada satu hal yang perlu dicatat bahwa stelah Rasulullah saw wafat, maka tidak ada lagi nasakh-mansukh terjadi pada syariat (Sukardi KD, 2002, p.173)

Jenis nasikh-mansukh yang diuraikan di atas memang segi formalnya. Jenis lain yang menyangkut segi materialnya, ada yang bersifat ekslusif (sharih) dan inklusif (dhanni). Untuk yang bersift eksklusif (sharih), nasikh itu langsung 
menjelaskan mansukhnya. Ketentuan yang nasikh di tetapkan secara jelas seperti halnya contoh dari Al Qur'an di atas. Sedangkan contoh sunah misalnya hukum ziarah kubur. Di dalam hadis disebutkan bahwa Nabi pernah melarang ziarah kubur sekarang diperbolehkan (Sukardi KD, 2002, p.173) Masalah naskh bukalan sesuatu yang berdiri sendiri. Ia merupakan bagian yang berada dalam disiplim ilmu tafsir dan ilmu ushul fiqh. Karena itulah naskh merupakan techniserterm dengan batasan pengertian yang baku. Dalam kaitan ini Imam Subki menerangkan adanya perbedaan pendapat tentang kedudukan naskh : apakah ia berfungsi mencabut (raf) atau menjelaskan (bayan). Ungkapan Imam Subki ini dapat dikaitkan dengan hal-hal yang menyangkut jenis-jenis naskh yang diuraikan di atas. Jika ditinjau dari segi formalnya maka fungsi pencabutan itu lebih nampak. Tapi bila ditinjau dari segi materinya, maka fungsi penjelasannya lebih menonjol. Meski demikian pada akhirnya dapat dilihat adanya suatu fungsi pokok bahwa naskh merupakan salah satu interpretasi hukum. (Sukardi KD, 2002, p.173)

\section{Hikmah Nasakh Mansukh}

Al Maragi dalam kitab tafsirnya melihat adanya hikmah keberadaan nasakh dengan menyatakan :'Sesungguhnya hukumhukum itu tidak diundangkan kecuali untuk kepentingan manusia. Hal ini dapat berbeda karena perbedaan waktu dan tempat. Jika suatu hukum diundangkan karena dirasakan perlu adanya hukum itu, kemudian keperluan itu berakhir, maka adalah suatu tindakan bijaksana menghapuskaan hukum itu dan menggantikannya dengan hukum yang lebih sesuai dengan waktu itu. Dengan demikian hukum menjadi lebih baik dari yang semula atau sama dari segi manfaat untuk hamba-hamba Allah."(Dewan Redaksi Enskopedi Islam, p.17) Manna Khalil al-Qattan menjelaskan tentang hikmah adanya nasakh dalam al-Quran, yaitu : 1) Menjaga keselamatan hamba Allah; 2) Perkembangan tasyri` menuju tingkat sempurna sesuai dengan perkembangan dakwah dan perkembangan kondisi umat Islam; 3) Cobaan dan ujian bagi Mukallaf untuk mematuhinya atau sebaliknya; dan 4) menghendaki kebaikan dan kemudahan bagi umat Islam. Sebab jika nasakh itu beralih kepada hal atau perkara yang lebih berat maka di dalamnya terdapat tambahan pahala, dan jika beralih kepada hal atau perkara yang lebih ringan maka nasakh mengandung kemudahan dan keringanan. (Manna Khalil al-Qattan, p.338)

\section{Kesimpulan}

Nasakh

adalah

menghilangkan, menghapuskan, membatalkan ayat dengan ayat yang lain karena adanya dalil yang menunjukkannya. Nasakh terjadi pada ayat yang berlawanan atau kontradiksi dengan ayat yang lain 
yang sulit untuk dikompromikan. Nasakh dan mansukh hanya berlaku terhadap ayat-ayat yang berkaitan dengan hukum syar'i yaitu terjadi pada perintah dan larangan. Nasakh tidak terdapat dalam akhlak, ibadah, akidah, dan juga janji dan ancaman Allah

Berkaitan dengan nasakh dan mansukh dikalangan ulama terdapat dua kelompok yang berseberangan. Pertama, golongan ulama yang menerima dan mendukung terjadinya nasakh dan mansukh. Kedua, golongan ulama yang menolak terjadinya nasakh dan mansukh. Terhadap kedua kelompok yang berbeda pendapat ini, diperlukan kompromi karena perbedaan kedua golongan ini memiliki implikasi terhadap ketetapan hukum yang dibutuhkan oleh masyarakat. Kompromi tersebut dilakukan dengan meninjau kembali istilah nasakh dan mansukh yang digunakan oleh ulama. Pemikiran Muhammad Abduh, mungkin dapat dijadikan jalan tengah terhadap perbedaan pendapat tersebut, meskipun Muhammad Abduh termasuk golongan yang menolak nasakh mansukh. Pemikiran tersebut adalah mengubah istilah nasakh mansukh sebagai penggantian/pengalihan/pemindahan ayat hukum di tempat ayat hukum yang lain.

Adapun bentuk-bentuk nasakh dan mansukh meliputi (1) Nasakh sharih (2) Nasakh Dzimmi (3) Nasakh kully (4) Nasakh Juz'i. Sedangkan otoritas mana yang berhak menghapus sebuah nasakh para ulama membagi nasakh ke dalam empat macam yaitu (1) nasakh al Qur'an dengan al Qur'an (2) nasakh al Qur'an dengan sunnah (3) nasakh Sunnah dengan al Qur'an (4) nasakh sunnah dengan sunnah

\section{Daftar Pustaka}

Aksin Wijaya, 2009, Arah Baru Studi Ulum Al-Qur'an : Memburu Pesan Tuhan di Balik Fenomena Budaya, Yogyakarta, Pustaka Pelajar

Al-Qattan , Manna Khalil, 2001, Studi Ilmu-ilmu al-Quran, terj. Mudzakir, Yogyakarta : Pustaka Lentera

Amir Syarifuffin, 2007, Ushul Fiqh, jilid I, Jakarta : Logos Wacana Ilmu

Anwar, Abu, 2009, Ulumul Quran, Sebuah Pengantar, Yogyakarta : Amzah

Anwar, Rosihan, 2007, Ulumul Quran, Bandung : Pustaka Setia

Basyir, Ahmad Azhar, 1998, "Reaktualisasi, Pendekatan Sosiologis Tidak Selalu Relevan", dalam Iqbal Abdurrauf Saimima (ed.), Polemik Reaktualiasi Ajaran Islam, Jakarta: Pustaka

Dewan Redaksi Enskopedi Islam, 1997, Ensiklopedi Islam, Jakarta, Ictiar Baru Van Hoeve

Elsaha, Ishom dan Hadi, Saiful, 2005, Sketsa al-Quran : Tempat, Tokoh, Nama dan Istilah dalam al-Quran, Jakarta : Lista Fariska

Hasan Asyari Ulama'I, 2016, Konsep Nasikh Dan Mansukh Dalam Al-Quran, Jurnal Didaktika Islamika Volume 7 Nomor 1 Pebruari 
Ichwan, Moh. Nor, 2002, Studi IlmuIlmu al-Quran, Semarang : RaSail Media Group

Khalaf, Abdul Wahhab, 1968, Ilmu Ushul Fiqh, ttp: Dar alKuwaitiyyah

Lihat, Jalaluddin Rahmat dkk. 2002, Belajar Mudah 'Ulum AlQur'an : Studi Khazanah Ilmu Al-Qur'an, Editor : Sukardi KD Jakarta, Lentera

Mansykur, Kahar, 2002, Pokokpokok Ulumul Qur'an, Jakarta : Rineka Cipta

Qardhawi , Yusuf, 1999, Berinteraksi dengan alQuran, Jakarta : Gama Insani Press

Quthb , Sayyid, Tafsir fi Zhilal alQur'an, Beirut: Dar al'Arabiyyah, t.th

Rachmat Syafe'i, 2006, Pengantar Ilmu Tafsir, Bandung : Pustaka Setia

Shihab, Quraish, 1994, Membumikan al-Qur'an Bandung : Mizan

Shihab, Quraish, 2004, Membumikan al-Quran, Fungsi dan Peran Wahyu dalam Kehidupan, Bandung : Mizan

Sjadzali, Munawir, 1985, PokokPokok Kebijaksanaan Menteri Agama dalam Pembinaan Kehidupan Beragama, Jakarta: Depag RI,

Sjadzali , Munawir, 1997, Ijtihad Kemanusiaan., Jakarta : Paramadina

Syafe`i , Rachmat, 2006, Pengantar Ilmu Tafsir, Bandung : Pustaka Setia

Taufiq, Imam. 2001, Maqamat dan Ahwal, Tinjauan Metodologis, dalam Tasawuf dan Krisis, Yogyakarta :
Pustaka Pelajar bekerja sama dengan IAIN Walisongo Press,

Yafie, Ali, 1998, Antara Ketentuan dan Kenyataan?, dalam Iqbal Abdurrauf Saimima (ed.), Polemik Reaktualiasi Ajaran Islam, Jakarta: Pustaka Panjimas

Yusuf, Kadar M., 2010, Studi al Qur'an, Jakarta: Amzah

Zahrah, Muhammad Abu, 2008, Ushul Fiqih, terj. Saefullah Ma`sum, dkk, Jakarta : Pustaka Firdaus 


\title{
The Influence of Guidance To Solve Problem In English Learning at SMP Al Akbar Brondong Lamongan
}

\author{
Rohmat Qosyim \\ Sekolah Menengah Pertama Al Akbar Brondong \\ Email:rohmat23@gmail.com
}

\begin{abstract}
Teachers sometimes are amazed at the extent to which a child's undesirable habit patterns can be reconditioned through the efforts of understanding teachers. At the same time, home influences may be so strong that there is little that teachers and counselors can do for the child unless he can be removed from unhealthful home surroundings. In most states, the parents have the legal right to device where their child shall live. Hence school people are helpless in such situations unless, by court action, the child is placed in an institution or foster home because of extreme parental neglect of or cruelty to the child, or gross immoral behavior on the part of one or both parents. Based on the background, the writer wants to do classroom action research with the title "The Influence of Guidance to Solve Problem in English Learning at SMP Al Akbar Brondong”.
\end{abstract}

Keywords: Influence of Guidance, Solve Problem, English Learning

Many of the adjustment problems of young people seem to reflect unhygienic home conditions. Parental attitudes and home and family situations that may lead to a young person's experiencing problems that need resolution include: family jealousies and dissensions; overindulgent, indifferent, or too strict parents; frequent moving of the family from one section of the city or country to another; too many or too few home duties; differences in ethical standards or religious affiliations among family members; low moral status; lack of home co-operation with the school or the community; homes broken by divorce of the death of a parent; homes that represent a culture that is foreign to that of the school community, and extremely low socio-economic status. (Lester D. Crow, and Alice Crow, 2006:526)

The first six years of a child's life are very important. Hence the six-year-old child who is a product of a home in which there are maladjustive factors is likely to reflect these unfavorable home conditions in undesirable attitudes and behavior patterns. Yet, teachers sometimes are amazed at the extent to which a child's undesirable habit patterns can be reconditioned through the efforts of understanding teachers. At the same time, home influences may be so strong that there is little that teachers and counselors can do for the child unless he can be removed from 
unhealthful home surroundings. In most states, the parents have the legal right to device where their child shall live. Hence school people are helpless in such situations unless, by court action, the child is placed in an institution or foster home because of extreme parental neglect of or cruelty to the child, or gross immoral behavior on the part of one or both parents.

School experiences. A learner may experience difficulties in adjusting satisfactorily to his learning experiences for one or more of several reasons. Some of these interfering factors can be and are overcome with the help of teachers who are alert to disturbing influences. With the aid of the administrative officers and counselors of the school, a teacher may be able to encourage whatever changes are needed to help the learner make a better adjustment to his learning activities. Other learner problems may represent a complex of conditions that cannot be improved by the school without the assistance of parents or other community agencies.

There are certain common situations or conditions that have been found by teachers to retard or to interfere with a young person's satisfactory adjustment to learning requirements. Among these are: lack of interest in school work or in specific school subjects; school curricula that are not graded appropriately to the learner's level of intelligence; too much or too little teacher assistance; poor study habits; too long or too difficult home study assignments; too much or too little competition among learners in terms of ability to compete; fear or failure; learner-teacher antagonisms; inadequate home-study conditions; too much or too little participation in the school's sports program or other cocurricular activities, or out-ofschool social activities; uncertainty about, or parent-child conflict concerning, vocational choice and preparation, and too great or too little parental interest in the child's school activities or learning progress. Some of these problems are experienced especially by secondary-school learners; some of them result from learner attitudes that have their roots in home-stimulated recognition of what should constitute desirable life values.

One of the most important functions of teachers and school counselors is to recondition the attitudes of some young people toward an appreciation of the value to themselves of achieving success in whatever educational opportunities are made available for them. Occupational requirements, social pressures, and educational encouragement are responsible for the fact that the upper limit of compulsory school attendance now ranges between the ages of sixteen and eighteen. There is a trend toward a school-leaving age of eighteen, except in emergency home conditions or in the case of a learner's giving evidence of inability to profit from further formal school learning. In every secondary school, however, can be found boys and girls whose one ambition is to leave school for a job, even though they are not yet prepared to perform adequately in any kind of job. Youth attitudes of this kind place upon 
school people the responsibility either to try to change a young person's attitude toward the value of education, or to offer a vocationally pointed curriculum that will prepare him for a job in which he has some chance of success.

Based on the background, the writer wants to do classroom action research with the title "The Influence of Guidance to Solve Problem in English Learning at SMP Al Akbar Brondong".

Based on the background of research, the problem of this research is as follows: How is the influence of guidance to solve problem in English learning at SMP Al Akbar Brondong?

According to statement of the problem, objective of this study is as follows: To know the influence of guidance to solve problem in English learning at SMP Al Akbar Brondong.

This study aims to develop quality of the students' achievement and to improve in English teaching leaning. The result of the study is to solve the problem in learning to get good achievement and the teacher gives guidance in English learning and teaching.

\section{Review Of Related Literature Guidance}

An understanding of the child is basic to any help or guidance that may be offered in his behalf. If we expect to be of aid to each learner as he attempts to make adjustments to the forces and factors in his environment, then those of us who are given the responsibility of promoting his welfare must prepare ourselves so that intelligent counsel and guidance may be offered. The child is forging ahead and needs to have the way prepared for him. He must come to understand its values and to recognize obstacles as well as him own potentialities as these are operative in his moving along that particular road.

Much has been written on guidance, personnel work, or counseling, yet there is little guidance in the way of its specific application to the actual work of the school. In its largest connotation guidance can be conceived of as being as broad as education itself. Any aid or assistance that is rendered a learner rightly can be considered to be guidance. However, guidance come to be interpreted as a phase of education that functions in relation to child development and adjustment. The functions of guidance are served best when an individual learner so is advised and aided that he is stimulated to make needed adjustments for the realization of his personal and social growth and satisfaction. There is an implied activity on the part of both the person who is being guided and the one who stimulates activities along welldirected lines of endeavor. From the point of view of the authors, "guidance is interpreted as a conscious, organized, directly or indirectly, to assist him in his adjustment to all phases of living. It is the handmaid of mental hygiene in education." (Lester D. Crow, and Alice Crow, 2004:571)

\section{The Influence of Guidance to Solve Problem in English Learning}

Pupils evince the need of guidance in mental activity, in behavior that has individual and 
social implications, and in the selection of a field of vocational work. Seldom can an individual, unaided, make his own choices or his own decisions for his own best interests.

It is true that the need of guidance is more easily recognized in times of crises when life runs along smoothly. However, if the right kind of guidance is experienced as a matter of course, it is wholly possible that a particular crisis confronting a young person can be avoided. It is the duty of the parent, the teacher, or the young leader to discover the personal problems of the young people for whom they are responsible and to help in the resolution of youthful conflicts. Among the conditions or situations that may bother young people can be included the following: physical characteristics, style of clothes, extent and kind of home duties, degree of success in school, recreational activity, degree of security or insecurity, attitude toward others, deciding about a vocation, and any one of a hundred or more real or imagined problems that face the young person during his maturing process.

As we consider the number of maladjusted individuals even in our own immediate environment, we recognize the need for more adequate guidance of child behavior and attitude. Delinquency is born in the environment, but if a child receives the proper help at the proper time he may be saved many trying experiences. "Parental" schools have come, have gone, and may come again. But delinquent behavior continues. As a result of an increase in delinquency, educational leaders in a certain large city are combining at the time of this writing in a recommendation that "bad" boys be segregated in a twenty-four-hour school so that may be trained in a carefully controlled environment. The need of guidance is recognized by any one who works with young people. A person, however, should not be expected or permitted to engage in guidance work unless he has received careful training in the utilization of techniques that have been helpful to workers in the field.

During the early years of the child, the guidance service provided for him center first in the home. When we refer to parental rearing of young children, it might be more accurate to describe parents' activities as those of guiding the child. Later, nursery-school and kindergarten teacher share with the parent the responsibility of introducing the child to the process of adapting himself to the requirements of an enlarging social world. Here the needed guidance activities include those of the teacher, the school nurse, and pediatrician and, of course, the parents. On this level, except in the case of the small child who already has become the victim of maladjustive influences, the main objective of guidance is prevention of difficulties. The youngsters are motivated to achieve self-awareness and self-confidence in their reactions to stimulating objects and situations and in their relations with their peers and older people. 


\section{Methode \\ Design of Study}

The research design in this study was the Classroom Action Research. Therefore the research was aimed at improving the teacherresearchers' own teaching. This classroom action research discussed about the influence of guidance to solve problem in English learning at SMP Al Akbar Brondong.

\section{Subject of the Study}

The subjects of the study were the eighth year students. In this study the researcher selected Class VIII as the subject. The population of students Class VIII was 32 students.

\section{Procedure of Study}

The procedure of research used in this study was a cyclical process adapted from the model proposed by Kemmis and Mc. Taggart. It consists of four steps, namely: planning, implementing, observing, and reflecting. These phases take place in every cycle. If in the first cycle the strategy has not solved the problem yet or the criteria of success have not been achieved, the strategy will be revised to continue to the second cycle. The cycle would continue to the next cycle with the same steps until the criteria of success are achieved.

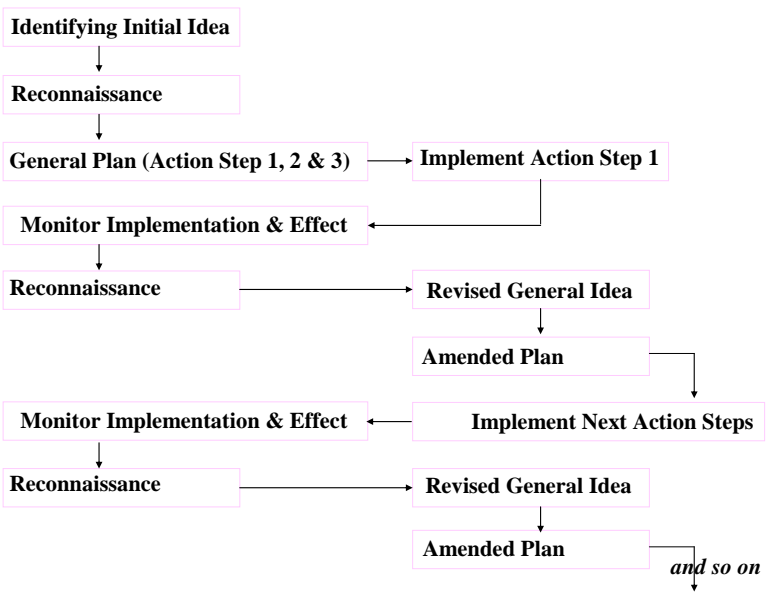

Figure 1: Procedure Classroom Action Research (Elliott)

The first step in planning make lesson plan. Preparing the lesson plan is very important the teaching learning process. It is made as a guide to conduct the instructional activity. The lesson plan is developed based on the syllabus of the school Based Curriculum. Planning should be complete and detail about everything will be done by researcher, include: action with its steps, subject, timing, instrument and so on. The implementation was to conduct the learning activity based on the plan. Observation is the process of recording and collecting data about any aspects or events which are happening during the implementation of the action. Reflection is the most important part of classroom action research. Reflection is a final phase of a cycle in which the researcher and the collaborative teacher evaluated the strength of the action implemented in the class. At this stage, the researcher wants to know the action, which is conducted is effective or not. 


\section{Data Analysis}

Analysis works with data, organize it, synthesize, search patterns, discover what is important and what is learned, and decide what will explain to the others (Bogdan and Biklen, 1982:145). To analyze the statistic data researcher uses mean, because it shows the mean score of students. The formula of mean is as follows:

$M=\frac{\sum f x}{N}$

$\mathrm{M}=$ the mean

$\sum=$ the sum of

$\mathrm{f}=$ frequency

$\mathrm{x}=$ score

$\mathrm{N}=$ number of the subjects

\section{Research Findings And Discussion Research Findings The First Cycle}

\section{Planning}

The first step in classroom action research is planning. It is very important to be done if want to get optimal result action of this research should be planned. To start this study the researcher and collaborator made some preparation before conducting the teaching and learning process including: Determining standard of competence, determining basic competence, making indicators, determining strategy in learning, determining the instructional materials, making the instruments for observation, and preparing media will be used in learning, as follows:
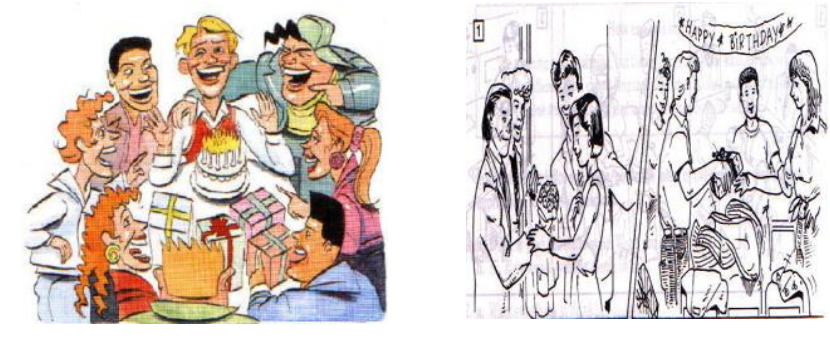

Implementing

To implement English teaching through guidance at SMP Al Akbar Brondong, there were some steps as follows: the teacher checked students' attendance, warming up to motivate students to study, grouping (a group consisted of four to five members), implementing the strategy in learning, and helping to the students had troubles in learning.

Read the following dialogues about complimenting Then, answer the questions that follow.

You : Happy birthday, Ed. Wow, what a cool present?

Edo : Thanks. Yes, it's a birthday present fro in Singapore.

You : Lucky you! I wish I had a watch like th

Edo : I hope you'll get a watch like this on yo

1) What are you complimenting?

2) Whom did Edo get the present from?

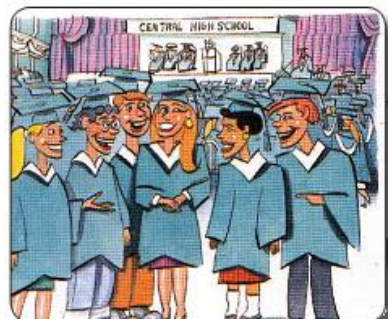

3) What is the occasion?

4) Why do they look happy?

5) What do they say to one another?

\section{Observing}

The researcher observed learning and teaching used guidance. To know the result of students' achievement used guidance as model 
of learning, it could be explained as follows.

From the mean score 69.47 it will be showed the total students whose success or fail. The success students are 18 students or $56.25 \%$ from the total testees. And the students who fail in the test are 14 students or $43.75 \%$ from the total testees. It means that $56.25 \%$ the items test is easy from them.

Based on the analysis of teaching and learning process and the students' achievement in the first cycle, the implementation of guidance had not met the criteria of success yet. For that reason, the researcher and his collaborator made a decision to continue the implementation of the study to the second cycle.

\section{The Second Cycle Planning}

Based on the research findings in terms of the weaknesses in the first cycle, the researcher and collaborator made an improvement and revision preparation before conducting the teaching and learning process for the second cycle including: Making the lesson plan, preparing the instructional materials, preparing the instruments would be used for observation making media would be used in learning, such as picture, slide, real object and so on.

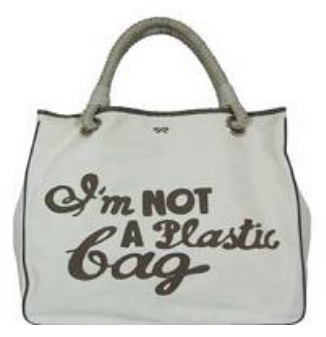

\section{Implementing}

As the first cycle, the implementation of the second cycle, the researcher acted as a teacher who conducted the teaching learning process, while the collaborator assisted to observe the teaching and learning process. The collaborator was also expected to write comments, either positive or negative, on the teaching and learning process, and identify the problems that might emerge during the teaching learning process. The implementation of the action was elaborated below: Giving warming up to motivate the students before studying, giving information to the students about the result in cycle 1 , the teacher explained the material of learning, the students asked difficult material to the teacher, making group consist three to four students, and the teacher gave problem about the material, such as:

Read the following dialogues about complimenting. Pra Then, answer the questions that follow.

You : Excuse me, but I was just admiring your bag.

Stranger : Oh, thank you.

You : Could you tell me where you got it? I have b like that for a long time.

Stranger : It's from the Luggage Store in Plaza Indonesi You : Oh, thank you very much.

1) What were you admiring?

2) Where did the stranger buy it?

3) Mention expression of complimenting!

Stranger : Oh, I love your earrings, they are so beautiful (in a lift)

You : Thank you. They're silver.

Stranger : I know. Are they Yogya silver?

You : No, they are Bali silver. I got them in Ubud.

Stranger : Oh, I see.

4) What are made of silver?

5) Where did you buy them?

The next, teacher checked the

result of learning, assisting the 
student who had problems in learning, and giving reinforcement about the material of learning in order to remember.

\section{Observing}

Observing had acted when the students implemented learning activities, observing in this cycle was looking the subject of study when implemented guidance, the result of students in this step as follows.

\section{Reflecting}

The researcher and the collaborator made some reflections on the implementation in order to determine the success or failure of the action. The reflections were focused on analysis of the teaching and learning process and analysis of the students' final products. The analysis was based on the obtained data from the observation checklists, field notes, and students' achievement.

After the writer computation of the mean score in this chapter, he found that the student's learning that shows their mean score around 75.38. From the mean score will be showed the total students whose success or fail. The success students are 24 students or $75 \%$ from the total testees. And the students who fail in the test are 8 students or $25 \%$ from the total testees. It means that $75 \%$ the items test is easy from them.

Based on the results of the teaching and learning process analysis and the scores of the students' achievement in the second cycle, it can be inferred that guidance could improve the students' achievement. This can be examined from the criteria of success described in this research. The students enjoyed learning using problem based learning. This can be seen from students' enthusiasm and motivation in following the activities, the students expressed without hesitation. Accordingly, it was considered reasonable to terminate the classroom action research.

\section{Discussion}

To know whether or not the teaching and learning process was successful, there must be an improvement on students' achievement. In this study, there has been a significant improvement on students' achievement compared with the teaching and learning process of achievement before using guidance was implemented.

The findings of this research showed that the students' achievement had improved significantly from one cycle to the following cycle. This could be seen from the results of each cycle. The first cycle had been implemented, the average score became 69.47. And the average score in the second cycle was 75.38. It means that the average score improve 5.91 from the first cycle to the second cycle. Since the mean score for every cycle show significant improvement and at the second cycle had met the criteria of success, the study can be stated as a successful piece of research. The improvement of students score can be seen in Figure 2.

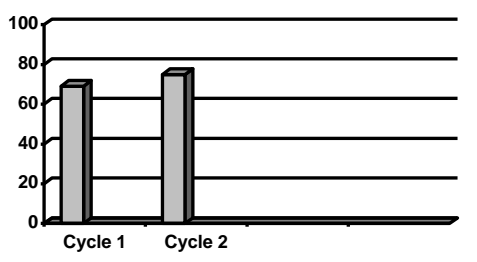




\section{Conclusion And Suggestion Conclusion}

Based on findings and discussion, finally the writer can take conclusion as follows: The students' achievement used guidance at SMP Al Akbar Brondong could be looked from the result of research. The first cycle had been implemented, the average score became 69.47. And the average score in the second cycle was 75.38. It means that the average score improve 5.91 from the first cycle to the second cycle. Since the mean score for every cycle show significant improvement and at the second cycle had met the criteria of success, the study can be stated as a successful piece of research.

\section{Suggestions}

Based on conclusion above, the writer can give suggestion, that: The students are expected to use brainstorming learning. Because the result of research shows that there is influence of guidance to the students' achievement, the teacher applies guidance.

\section{Bibliography}

Chisholm. 2000, Guiding Youth in the Secondary School, America Book Company, New York.

Cohen. 2002, Children in Trouble, Norton, New York.

Davis. 1999, Guidance Handbok for Teachers, McGraw-Hill, New York.

Froehlich. 1989, Guidance Services in Smaller School, McGrawHill, New York.

Lester D. Crow, and Alice Crow. 2004, Educational Psychology, America Book Company, New York.

Lester D. Crow, and Alice Crow. 2006, Human Development and Learning, America Book Company, New York.

Symonds. 1999, The Dynamics of Parent-Child Relationship, Columbia University Press, New York.

Torgerson. 2007, Studying Children, The Dryden Press, New York. 


\title{
Cara Mudah Menghafal Al Qur'an Melalui Metode Tarjim Di Pondok Pesantren Tahfidzul Qur'an Safinatul Huda Iii Bandung Diwek Jombang
}

\author{
Sunardi \\ Sekolah Tinggi Ilmu Tarbiyah al Urwatul Wutsqo - Jombang \\ Email: sunardi.ppuw@gmail.com \\ Kamaliyatul Izzah Muqoddasah \\ Universtas Pesantren Tinggi Darul Ulum - Jombang \\ Email: Kamaliya41@gmail.com
}

\begin{abstract}
Everyone has their own method or method of memorizing. But the most widely used are those that are suitable and enjoyable for each individual. When examined, most methods suitable for each person are obtained through several attempts. The method or method of memorizing effective Al-Qur'an applies diversity not uniformity. That is, between one person and another, the same method applies, depending on the character, absorption and memory of each. This method proved to be accurate for someone not necessarily accurate for others. The purpose of this study is to investigate the implementation of the tarjim method, the supporting and inhibiting factors in memorizing the Qur'an. The application of the tarjim method is a foreign grammar study that emphasizes grammar analysis, vocabulary memorization, discourse translators, and writing exercises. This method emphasizes reading, writing and translation skills.
\end{abstract}

Keywords: Memorizing Al-Qur'an, Tarjim Method

\begin{abstract}
Abstrak: Setiap orang memiliki cara atau metode sendiri dalam menghafal. Namun yang paling banyak digunakan adalah yang cocok dan menyenangkan bagi tiap individu. Jika diteliti, kebanyakan metode yang cocok bagi setiap orang diperoleh melalui beberapa kali percobaan. Hal atau cara metode menghafal AlQur'an yang efektif berlaku keberagaman bukan keseragaman. Maksudnya, antara satu dan lain orang berlaku metode yang tidak sama, tergantung pada karakter, daya serap dan daya ingat masing-masing. Metode ini terbukti jitu bagi seseorang belum tentu jitu pula bagi orang lain. Tujuan penelitian ini untuk mengetuahi bentuk implementasi metode tarjim, faktor pendukung dan penghambat dalam menghafal Al-Qur'an. Penerapan metode tarjim merupakan kajian tata bahasa asing yang menekankan analisa tata bahasa, penghafalan kosa kata, penerjemah wacana, dan latihan menulis. Metode ini mementingkan kecakapan membaca, menulis, dan terjemah.
\end{abstract}

Kata Kunci: Menghafal Al-Qur'an, Metode Tarjim 
Al-Qur'anul karim adalah mukjizat Islam yang kekal dan mukjizatnya selalu diperkuat oleh kemajuan ilmu pengetahuan. Ia diturunkan Allah SWT kepada Rasulullah, Muhammad SAW untuk mengeluarkan manusia dari suasana yang gelap menuju yang terang, serta membimbing mereka kejalan yang lurus. (Manna Khalil al-Qattan, 2014:1). Melalui penghafal AlQur'an Allah menjaga keutuhan kitab suci-Nya. Tingginya kesadaran umat Islam untuk menghafal AlQur'an semakin mengokohkan AlQur'an sebagai kitab suci yang paling banyak dihafal. Kaum muslimin menghafalkan ayat demi ayat, surah demi surah dan juz demi juz kemudian menyimpannya di dada mereka. Sehingga mustahil bagi mereka yang anti islam untuk mengubah atau memalsukan AlQur'an.

Penghafal Al-Qur'an adalah manusia pilihan Allah SWT, mereka sangat istimewa di sisi Allah, Allah meninggikan kedudukan mereka baik didunia maupun diakhirat. Mereka menjaga kalamullah maka mereka pun dijaga oleh Allah SWT. Mereka memuliakan Al-Qur'an maka Allah pun akan memuliakan mereka. Ada berjuta keistimewaan yang dimiliki oleh kafilah Qur'an. Rasulullah SAW pernah bersabda :

$$
\begin{aligned}
& \text { إنَّ لِلّهِ أَهْلِينْنَ مِنَ النَّاسِ. قِيْلَ مَنْ هُمْ يَا رَسُوْلَ اللهِ ؟ }
\end{aligned}
$$

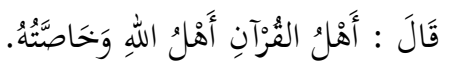

$$
\begin{aligned}
& \text { "Sesungguhnya Allah } \\
& \text { mempunyai keluarga di } \\
& \text { antara manusia" para } \\
& \text { sahabat pun bertanya : } \\
& \text { "Siapakah mereka wahai } \\
& \text { Rasulullah ?"Beliau } \\
& \text { menjawab : "Para ahli Al- }
\end{aligned}
$$

Qur'an, mereka lah keluarga Allah dan pilihan-pilihanNya. "(Imam Abdul Rouf An-Nawawi, Jami'u Shogir, th.:72)

$$
\text { خَيْرِكُمْ مَنْ تَعَلَّمَ الُْقرآنَ وَعلَّمَمُه }
$$

"Sebaik-baik orang di antara kalian adalah orang yang mempelajari (al-Qur'an dan mengajarkannya." $H R$. Bukhari) (Imam Abdul Rouf An-Nawawi, th.12)

Hadits ini mengisyaratkan bahwa kebaikan seseorang bisa dilihat dari kesungguhannya dalam belajar dan mengajarkan Al-Qur'an. Seolah-olah kemuliaan seseorang bisa dilihat dari keakrabannya dengan Al-Qur'an, baik dalam mempelajari, mengajarkan, membaca, menghafal, mentadaburi, dan mengamalkannya. Al-Qur'an menjadi takaran baik buruknya manusia dihadapan Allah Swt. (Saied Al-Makhtum, 2016: 23-26). Sebagian besar umat Islam beranggapan bahwa menghafal AlQur'an itu susah. Diantara penyebabnya pertama, mereka belum meyakini ayat Allah yang menegaskan kemudahan Al-Qur'an. Kedua, belum pernah serius menghafalkannya. Biasanya yang mengatakan bahwa menghafal itu susah, mereka belum pernah menghafal atau pernah menghafal tapi tidak serius, alias hanya cobacoba. Lantas ketika mendapat sedikit kesulitan, mereka langsung berhenti menghafal, lalu mengatakan bahwa menghafal itu susah.

Nikmatnya menghafal itu justru di saat ada sedikit kesulitan, karena itulah kesempatan anda 
untuk lebih banyak membaca, mengulang dan mendalami maknanya. Orang yang merasakan nikmatnya menghafal biasanya ingin menikmati hafalannya lebih lama. Ibarat makan, ia tidak terburuburu untuk mengakhiri hidangannya.

Al-Qur'an adalah kitab suci yang paling mudah dipelajari dan dihafal. Salah satu buktinya adalah Al-Qur'an merupakan satu-satunya kitab yang paling banyak dihafal oleh manusia di dunia. Ini selaras dengan firman Allah dalam AlQur'an :

"Dan Sesungguhnya Telah kami mudahkan Al-Quran untuk pelajaran, Maka Adakah orang yang mengambil pelajaran?" (QS. Al-Qomar : 17) (Departemen Agama RI, 2010: 529-530).

Setiap orang memiliki cara atau metode sendiri dalam menghafal. Namun demikian, yang paling banyak digunakan adalah yang cocok dan menyenangkan bagi tiap individu. Jika diteliti, kebanyakan metode yang cocok bagi setiap orang diperoleh melalui beberapa kali percobaan. (Amjad Qosim, 2013:101)

Hal atau cara metode menghafal Al-Qur'an yang efektif berlaku keberagaman, bukan keseragaman. Maksudnya, antara satu dan lain orang berlaku metode yang tidak sama, tergantung pada karakter, daya serap dan daya ingat masing-masing. Metode ini terbukti jitu bagi seseorang belum tentu jitu pula bagi orang lain. Berkaitan dengan ini, ada orang-orang yang dapat menemukan sendiri metode yang tepat bagi mereka. Tetapi tak sedikit pula orang yang bingung dan perlu menimba pengalaman orang lain serta bimbingan guru untuk sampai pada metode yang tepat bagi dirinya.

Menghafal Al-Qur'an adalah proyek kita meninggalkan dunia, dengan derajat yang istimewa, dan tempat yang dijanjikan adalah surga. Oleh karenanya, jujurlah kepada Allah, maka Allah akan jujur kepada anda. Jadikanlah Al-Qur'an sebagai prioritas dalam hidup anda, maka anda akan mampu menghafalnya. Anda juga akan mengamalkannya, dan Al-Qur'an pun akan menggiring anda untuk masuk ke dalam surga yang penuh dengan sungai-sungai. (Majdi Ubaid Al-Hafizh, 2014:2930).

"Di tempat yang disenangi di sisi Tuhan yang berkuasa." $(Q S$. Al-Qomar : 55)(Departemen Agama RI, 2010:53)

Kita diperintahkan oleh Allah untuk menetapi Al-Qur'an dan mengamalkannya sepanjang siang dan malamsecara total. Selain itu juga, merenungkan ayat-ayat dan menghayati maknanya.

Katakanlah: "Sesungguhnya Aku hendak memperingatkan kepadamu suatu hal saja, yaitu supaya kamu menghadap Allah (dengan ikhlas) berdua- dua atau sendiri-sendiri; Kemudian kamu fikirkan (tentang Muhammad) tidak ada penyakit gila sedikitpun pada kawanmu itu. dia tidak lain hanyalah pemberi peringatan bagi kamu sebelum (menghadapi) azab yang keras" (Saba' :46) 
Berapa banyak orang yang membaca Al-Qur'an, mempelajari serta menghafalnya, tetapi cahaya iman belum merasuk kedalam hatinya sehingga tidak semakin meningkat keimanannya secara langsung. Terhadap orang seperti ini, maka Al-Qur'an akan menjadi penentang yang mencelakakannya, bukan pembelanya.

\section{Pondok Pesantren Tahfidzul}

Qur'an Safinatul Huda Bandung Diwek selalu mengikuti perkembangan zaman, di pondok ini menggunakan beberapa metode untuk meningkatkan kemampuan menghafal Al-Qur'an bagi para santri. Salah satu metode yang digunakan di pondok ini untuk membantu santri dalam menghafal Al-Qur'an ialah dengan metode tarjim. Metode tarjim adalah metode yang menekankan pada pengapalan kosa kata (mufrodat) dan penerjemahan ayat-ayat Al-Qur'an. Tidak bisa dipungkiri bahwa orang yang memahami makna dan kandungan ayat-ayat yang akan dihafal akan lebih mudah untuk menghafalkannya. Jika kita rutin setiap hari menjaga dan menambah hafalan, daya ingat akan terpelihara. Selain itu bagi yang menerapkan metode menghafal dengan mengetahui artinya terlebih dahulu, maka hal ini akan mendapatkan pemahaman yang lebih baik tentang isi Al-Qur'an. Membaca dan menghafalkan Al-Qur'an juga akan memberikan ketenangan hati dan dapat memberikan pertolongan atau syafa' at di hari kiamat.

Berbicara tentang menghafal Al-Qur'an, santri dipondok pesantren Tahfidzul Qur'an Safinatul Huda III seluruhnya adalah penghafal AlQur'an. Pada tahap awal dan belum resmi menjadi pesantren hanya berjumlah 9 santri, tetapi sekarang sudah mencapai lebih dari 250 santri, karena keterkaitannya dengan metode yang diterapkan dipondok tersebut.

Setelah peneliti melakukan observasi di Pondok Pesantren Tahfidzul Qur'an Safinatul Huda III Bandung Diwek Jombang, peneliti mendapatkan informasi bahwasanya penerapan metode tarjim di bagi menjadi dua kelompok, yakni hari jum'at, sabtu, dan ahad untuk kelompok pertama dan hari senin, selasa dan rabu untuk kelompok kedua. Adapun untuk hari kamis mereka isi dengan kegiatan rutinan Pondok tiap kamis malam Jum'at.

Pondok pesantren Tahfidzul Qur'an Safinatul Huda didirikan oleh Kiai Ghozi Rofi'udin, S.HI. Berdirinya ini adalah atas dasar ingin mencetak generasi muda hamilil Qur'an, hafidhul Qur'an, lafdhan wa ma'nan wa 'amalan.Santri di pondok Pesantren ini rata-rata menyelesaikan hafalan dalam jangka cepat. Adapun santri yang kemampuan menghafalnya tinggi mampu menyelesaikan hafalan hanya dalam waktu singkat. Ini suatu upaya pengasuh untuk mewujudkan masyarakat yang paham Al-Qur'an dan menjadi manusia yang cerdas dan berbudi luhur.

Penelitian ini, difokuskan pada menghafal Al-Qur'an di Pondok Pesantren Tahfidzul Qur'an Safinatul Huda III. Berdasarkan penelitian diataslah maka peneliti mengambil judul : "Implementasi Metode Tarjim dalam Menghafal AlQur'an di Pondok Pesantren 
Tahfidzul Qur'an Safinatul Huda III Bandung Diwek Jombang".

\section{Fokus Penelitian}

1. Implementasi metode tarjim di Pondok Pesantren Tahfidzul Qur'an Safinatul Huda III Bandung Diwek Jombang.

2. Faktor pendukung dan penghambat dalam menghafal Al-Qur'an melalui metode tarjim di Pondok Pesantren Tahfidzul Qur'an Safinatul Huda III Bandung Diwek Jombang.

\section{Metode Penelitian}

Penelitian tentang Cara

Menghafal Al Qur'an Melalui Metode Tarjim di Pondok Pesantren Tahfidzul Qur'an Safinatul Huda III Bandung Diwek Jombang ini menggunakan jenis penelitian lapangan (field research) menggunakan paradigma penomenologi dan pendekatan penelitian kualitatif. Sumber penelitian ini meliputi orang yaitu kyai, para ustadz dan ustadzah,para senior, dan santri. Sumber data yeng berupa tempat adalah sarana, dan prasarana kerja dan aktivitas di Pondok Pesantren Tahfidzul Qur'an Safinatul Huda. Sedangakan data sekunder berupa dokumen, yaitu beberapa arsip pondok yang berkaitan dengan profil Pondok Pesantren Tahfidzul Qur'an Safinatul Huda, dokumen, buku-buku, catatancatatan, buku absen, buku rapat dan lain sebagainya yang berkaitan dengan penelitian ini.

Teknis pengupulan data dalam penelitian ini menggunakan Interview (wawancara), observasi dan dokumentasi. Sedangkan teknis analisis data penelitian ini menggunakan redukasi data, penyajian data dan verifikasi data.

\section{Pembahasan}

1. Implementasi Metode Tarjim dalam Menghafal Al-Qur'an di Pondok Pesantren Tahfidzul Qur'an Safinatul Huda III Bandung Diwek Jombang

a. Implementasi

1) Metode Tarjim Menghafal Al-Qur'an adalah bentuk taqarrub kepada Allah yang paling agung. Nabi Muhammad SAW bersabda :

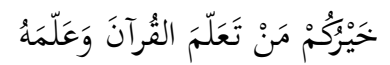

"Sebaik-baik kalian adalah orang yang belajar AlQur'an dan mengajarkannya." (HR. Bukhari) (Imam Abdul Rouf An-Nawawi, 12)

Menghafal Al-Qur'an itu, terdapat metode khusus yang dipakai oleh calon tahfidz. Penerapan metode tarjim merupakan kajian tata bahasa asing yang menekankan analisa tata bahasa, penghafalan kosa kata, penerjemah wacana, dan latihan menulis. Metode ini mementingkan kecakapan membaca, menulis, dan terjemah. Bisa disebut klasifikasi dari segi isim, fi'il atau huruf. Kemudian, jika ada kosa kata yang lupa, maka diperbolehkan membuka kamus lafdzul Qur'an 
dengan tujuan untuk mengingat kembali kosa kata atau terjemah yang sudah dihafal. Sebagaimana yang diceritakan Kiai Ghozi Rofi'udin kepada peneliti bahwa:

Metode tarjim adalah mempelajari Al-Qur'an melalui kemampuan berbahasa Arab (pendekatan kosa kata). Penerapan metode tarjim bermodel kelompok. Satu ustadz/ah membawai maksimal 20 santri dan kemudian pelatihan diadakan satu hari cukup satu jam untuk memahami metode tarjim tersebut. Metode tarjim mempunyai buku atau media belajar dalam memahami Al-Qur'an secara lafdhiyah atau perkata (kamus Lafdzul Qur'an dan program Pelatihan Terjemah AlQur'an). Dalam buku tersebut lafazh yang tercetak merah adalah kata baru, karena di dalam Al-Qur'an banyak kata yang diulangulang, maka semakin banyak yang dipelajari semakin sedikit lafadz yang tercetak merah, itu berarti semakin mudah untuk kita memahaminya. Kamus tersebut dibagi secara per juz, karena setiap juz mempunyai klasifikasi lafadz yang berbeda. Seperti juz 1 lafdhiyah atau perkata, terjemah bahasa Indonesia dan klasifikasi lafadznya dari segi isim, fi'il atau huruf. (Kiai Ghozi Rofi'udin, 27 April 2017, jam 13.00 WIB)

Hal senada diungkap oleh ustadzah Nur Ummatul Khiftia kepada peneliti bahwa:

Metode tarjim itu metode terjemahan yang dipakai untuk memahami AlQur'an, dengan begitu kita bisa dapat mengetahui isi Al-Qur'an. Disini menggunakan metode tarjim perkata, ada buku tersendiri untuk pembelajaran metode tarjim. Dalam penerapan metode tarjim ini dibagi menjadi dua kelompok, setiap kelompok terdiri dari 20 orang. Tak bisa dipungkiri bahwa santri yang menerapkan metode tarjim dalam menghafal AlQur'an melalui pemahaman makna ayat-ayat yang akan dihafal lebih mudah untuk masuk ke otak. Khususnya ketika menghafal surat-surat yang mengandung kisah atau ayat-ayat yang mempunyai sababun nuzul (sebab turun) yang sudah sangat popular. Begitu juga dengan ayat-ayat yang berkaitan dengan hukumhukum fiqh, seperti berwudhu, kafarat sumpah, kafarat zihar, puasa, diyat pembunuhan bersalah, atau hukum-hukum lainnya. (Nur Ummatul Khiftia, 14 April 2017, jam 13.00 WIB)

Penerapan metode tarjim di Pondok Pesantren Safinatul Huda III Bandung Diwek 
Jombang sebagai berikut pertama Satu kelas maksimal 20 santri yang dibawai oleh satu ustadz. Kedua, Menyiapkan Mushaf beserta kamus Lafdzul Qur'an sebelum memulai menerapkan metode tarjim. Ketiga, Membaca dengan tartil 1 kaca atau satu halaman yg akan diterjemahkan.

Ketiga,Membaca satu ayat kemudian diterjemahkan perpotong. Keempat, Setelah menerjemahkan perpotong, dilanjutkan menerjemah secara langsung dalam satu ayat. Kelima, Jika ada arti yang lupa diperbolehkan untuk membuka kamus Lafdzul Qur'an. Keenam, Setelah selesai penerjemahan satu halaman, maka diulang kembali dari awal dengan mengartikan per ayat. Ketujuh, Untuk mengetahui seberapa keberhasilan santri dalam menghafal melalui metode tarjim, maka akan diadakan evaluasi pada tiap pergantian juz. (Nur Ummatul Khiftia, 4 April 2017, jam 13.00 WIB)

2) Hukuman

Hukuman yang diberikan oleh pengurus kepada santri yang melanggar peraturan yaitu Pertama, Digundul apabila ketahuan merokok atau berpacaran. Kedua, Dihukum berdiri sambil mengaji apabila ketahuan pergi ke warnet. Ketiga, Ro'an apabila tidak mengikuti kegiatan malam di pondok. Keempat, Apabila telah melanggar peraturan lebih dari $3 \mathrm{x}$ maka akan dikeluarkan dari pondok, begitu juga apabila ada kasus disekolahnya.

3) Bentuk kegiatan

Kegiatan para santri setiap hari dan bulanan yang dilaksanakan di Pondok adalah, Khutbah dan Adzan, Hataman yang dilaksanakan setiap Kamis Legi di masjid Safinatul Huda III, Hataman di luar Pondok ketika ada undangan, Muhadhoroh, Puisi dan Pantun, MQQ dan MHQ, MFQ (CCQ), Banjari (Diba'an)

4) Jadwal kegiatan

Selain menghafal AlQur'an, di Pondok Pesantren Safinatul Huda III Bandung Diwek Jombang juga ada kegiatan pengajian kitab dan Qiro'ah, berikut jadwal pengajian kitab dan qiro'ah. Jadwal Pengajian Kitab di Pondok Pesantren Tahfidzul Qur'an Safinatul Huda III

Pengaplikasian metode tarjim dalam menghafal al-Qur'an di Pondok Pesantren tahfidzul Qur'an safinatul huda III Bandung Diwek Jombang

Mengaplikasikan metode tarjim, perlu melihat konsep dasar metode ini sebagaimana dijelaskan agar tidak keluar dari karakteristiknya, karena Al-Qur' an mudah dihafal dan mudah hilang dari ingatan. Hafalan yang sudah disetorkan ke instruktur dan tersimpan di 
memori otak belum terjamin akan terjaga terus melekat selama-lamanya. Hafalan dapat bertahan paling lama 12 jam. Upaya ustadz/ustadzah dalam mendidik santrinya menghafal Al-Qur'an adalah dengan memberikan motivasi dan dukungan penuh terhadap santri melalui pengkajian dan pengarahan atas keistimewaan pahala orang yang menghafal Al-Qur'an. Selain memberikan motivasi kepada santri, ustadz/ustadzah juga selalu memberikan pengkajian ilmu tajwid, sehingga santri tidak hanya lancar menghafal AlQur'an saja akan tetapi lancar makhraj dan tajwidnya dengan benar dan baik. Hal ini didukung dengan pernyataan bapak Kiai Ghozi Rofi'udin yang menyatakan bahwa:

Ustadz/ustadzah adalah orang yang pertama menjadi dasar penentu keberhasilan santrinya, berhasil tidaknya hafalan santri tergantung pengembangan pengajaran ustadz/ustadzah. Selain memberikan motivasi kepada santri, ustadz/ustadzah juga harus memberikan pengkajian ilmu tajwid, sehingga santri tidak hanya lancar menghafal Al-Qur'an. Pada prinsipnya, orang menghafal Al-Qur'an itu tidak boleh lupa atau melupakan hafalannya. Kalau itu terjadi, sia-sialah pekerjaan yang telah dia lakukan. Seharusnya apa yang sudah dihafal dengan metode-metode yang baik tidak lepas dan hilang dari ingatan. Hanya saja, begitulah kenyataan yang sering terjadi banyak orang yang dulunya hafal Al-Qur'an dengan lancar, kini tidak lagi, atau banyak dari hafalannya yang hilang karena tidak rajin melakukan takrir. (Kiai Ghozi Rofi'udin, 27 April 2017, jam 13.00 WIB) Ungkapan sama juga dari Adin Rajabi, dia mengatakan bahwa: Saya itu bisa menghafalkan AlQur'an karena dapat motivasi dari guru saya, saat itu saya masih kelas 3 MI. beliau berkata bahwa, kalau kita ingin menjadi keluarga Allah kita harus hafalan Al-Qur'an. Kita harus berkaca kepada orang yang lebih dari pada kita, dan kita harus bisa seperti dia. Agar hafalan kita bisa lebih terjaga, kita harus lebih sering nderesnya dari pada malasnya. Disini diadakan muroqobah 1 juz tiap harinya agar hafalan santri itu lebih terjaga dan lebih melekat dalam ingatan santri. (Kiai Ghozi Rofi'udin, 27 April 2017, jam 13.00 WIB) Berdasarkan hasil wawancara dengan Ustadzah Nur Ummatul Khiftia selaku ketua Pondok Putri pada tanggal 14 april 2017, pengaplikasian metode tarjim di Pondok Pesantren Tahfidzul Qur'an Safinatul Huda III melalui takrir (mengulang hafalan), antara lain : Pertama, Takrir sendiri ialah Seorang yang menghafal Al-Qur'an harus bisa memanfaatkan waktu untuk takrir dan menambah hafalan. Hafalan yang baru harus selalu di takrir, minimal dua kali sehari dalam jangka 
waktu satu minggu. Sedang hafalan yang lama harus di takrir setiaphari atau dua hari sekali. Artinya semakin banyak hafalan harus semakin banyak pula waktu yang dipergunakan untuk takrir. Kedua, Takrir dalam sholat ialah Seorang yang menghafal Al-Qur'an hendaknya bisa memanfaatkan hafalannya sebagai bacaan dalam shalat, baik sebagai imam maupun dalam shalat sendiri. Selain menambah keutamaan (pahala), cara demikian juga akan menambah kemantapan hafalan. Ketiga, Takrir bersama ialah Seorang yang menghafal Al-Qur'an perlu melakukan takrir bersama dengan dua teman atau lebih. Dalam takrir ini setiap orang yang membaca materi takrir yang ditetapkan secara bergantian, misalnya masing-masing satu halaman, dua halaman atau ayat per ayat. Ketka seorang membaca, yang lain mendengarkan dan membetulkan jika ada yang salah. Keempat,Takrir kepada Instruktur atau Guru ialah Seorang yang menghafal AlQur'an harus selalu menghadap instruktur atau guru untuk takrir hafalan yang sudah diajukan. Materi takrir yang dibaca harus lebih banyak dari pada materi tahfidz, yaitu satu banding sepuluh. Artinya, apabila penghafal sanggup menyetorkan hafalan baru dua halaman setiap hari, maka harus diimbangi dengan takrir 20 halaman (satu juz).
Dalam proses menghafal AlQur'an, keinginan cepat khatam 30 juz memang sangatlah wajar. Namun jangan sampai keinginan tersebut membuat anda terburu-buru dalam menghafalkan AlQur'an dan pindah kehafalan yang baru. Sebab bila demikian, dikhawatirkan akan melalaikan hafalan yang sudah pernah dihafal tidak diulang kembali karena lebih fokus pada hafalan baru dan tidak mentakriri hafalan yang lama. Hal ini didukung dengan pernyataan Kiai Ghozi Rofi'udin yang menyatakan bahwa:

Jika menginginkan kualitas hafalan yang baik dan kuat, maka sebaiknya jangan terburu-buru ketika menghafalkannya. Oleh karena itu, jangan tergesa-gesa berpindah ke ayat yang lain hingga ayat yang sebelumnya benar-benar hafal dan kuat. Selain itu juga, tidak hanya fokus ke perpindahan surat yang sebelumnya, tetapi harus fokus ke surat yang terdahulu yang sudah pernah dihafalkan. (Kiai Ghozi Rofi'udin, 27 April 2017, jam 13.00 WIB)

2. Faktor pendukung dan penghambat menghafal al-Qur'an melalui metode tarjim

Menghafal Al-Qur'an, tidak lepas dari faktor pendukung dan penghambat yang berkenaan dengan metode tarjim di Pondok Pesantren Tahfidzul Qur'an Safinatul Huda III Bandung Diwek Jombang. Diantara faktor yang mendukung dalam menghafal Al-Qur'an di Pondok 
Pesantren ini adalah karena adanya kerjasama dari pengasuh, pengurus dan ustadz dalam memotivasi, membimbing dan memberi suri tauladan kepada santri dan dalam membimbing santri untuk menghafal Al-Qur'an.

a. Faktor pendukung dalam menghafal al-Qur'an melalui metode tarjim

Berdasarkan hasil wawancara dengan Pengasuh Pondok, Ustadz dan para santri pada tanggal 15 April 2017, faktor pendukung dalam menghafal Al-Qur'an antara lain : Pertama, Memperbaiki bacaan sebelum menghafal ialah Sebelum memulai menghafal Al-Qur'an, pastika bacaan sudah benar terlebih dahulu. Dianjurkan untuk mulai mencoba belajar Ilmu Tajwid. Disimak oleh Syaikh AlHafidz terlebih dahulu sebelum mulai menghafal. Sebab, seseorang yang menghafal dengan bacaan yang salah, nantinya akan sulit untuk memperbaiki bacaannya. Hal ini bukan berarti menganjurkan untuk menunda menghafal sampai selesai belajar tajwid, tapi justru menganjurkan untuk segera menghafal dengan tetap mencari kesempatan untuk memperbaiki bacaan. Misalnya dengan mendengarkan kasetkaset bacaan Syaikh AlMinsyawi atau Al-Hasri sebelum mulai menghafal halaman tertentu bagi yang belum belajar Ilmu Tajwid. Hal ini didukung oleh pernyataan Kiai Ghozi Rofi'uddin yang menyatakan bahwa:
Seperti kita ketahui, Al-Qur'an itu diturunkan ditanah Arab dengan bahasa Arab pula. Kita yang bahasa sehari-harinya bukan Arab, tentu harus banyak belajar dalam hal pengucapan Arab. Dalam menghafal Al-Qur'an, kita harus menguasai ilmu tajwid. Allah SWT memerintahkan kepada seluruh umat Islam agar membaca Al-Qur'an dengan benar sesuai dengan yang telah ditetapkan dalam ilmu tajwid. Karena itu, menguasai ilmu tajwid terlebih dahulu sebelum membaca AlQur'an, apalagi menghafalkannya adalah perkara wajib. (Kiai Ghozi Rofi'udin, 27 April 2017, jam 13.00 WIB).

Hal senada diungkap oleh Ihya'ul Ulum kepada peneliti bahwa:

Membaca Al-Qur'an memang dibutuhkan keterampilan dan kemampuan dalam hal pengucapan. Sebab bila pengucapannya salah, maka hal itu dapat mengurangi, bahkan menghapus dari pahala membaca Al-Qur'an. Sebagaimana kita ketahui, membaca satu huruf saja mendapat pahala sepuluh kali lipat, bagaimana jika membaca satu ayat, satu surat, satu juz, atau bahkan khatam. Jadi menguasai ilmu tajwid itu sangat penting sebelum kita membaca atau menghafalkan Al-Qur'an. (Kiai Ghozi Rofi'udin, 27 April 2017, jam 13.00 WIB) 
Kedua, Menggunakan mushaf Al-Qur'an dari satu cetakan ialah Sebagaimana kita ketahui bersama, bahwa Al-Qur'an telah dicetak dalam berbagai corak serta gaya tulisan yang beragam, baik dari segi bentuk maupun ukurannya. Selain itu, ada Al-Qur'an yang satu halamannya berisi dua belas baris, empat belas baris, lima belas baris, serta beberapa corak dan bentuk Al-Qur'an lainnya. Ketiga, Mampu menyambung dari awal sampai akhir sebelum berpindah ke surat lain. Menyambung hafalan antara ayat satu dengan lainnya lebih diutamakan dari pada menghafal ayat-ayat baru. Pastikan dapat menyambung setiap ayat dengan ayat berikutnya, dan jangan mulai menghafal ayat baru kecuali jika hafalan sudah benar-benar kuat dalam menyambungkan ayat-ayat sebelumnya. Keempat, Menentukan target hafalan setiap hari. Seorang santri harus menentukan target hafalan setiap harinya, sebab pikiran bawah sadar serta kemampuan otak lebih memahami hal-hal yang terperinci dan tidak menyukai hal-hal yang bersifat umum.

Sebagaimana yang diceritakan oleh Kiai Ghozi Rofi'uddin kepada peneliti bahwa:

Sebaiknya tidak tidur malam kecuali setelah menyelesaikan target hafalan, baik 7 halaman atau 7 baris. Point terpenting adalah menentukan rincian target hafalan setiap harinya dan jangan mengubah jadwal

$\begin{array}{lrr}\text { harian sampai } & \text { bisa } \\ \text { menghafalkannya } & \text { dengan } \\ \text { sempurna. } & \text { (Kiai } & \text { Ghozi } \\ \text { Rofi'udin, 27 April } & \text { 2017, jam } \\ \text { 13.00 WIB) } & \\ \text { Kelima, Melazimi } & \text { Halaqah } \\ \text { Tahfizh ialah Sering kita dapati } \\ \text { seseorang yang rangat } \\ \text { bersemangat r melakukan } \\ \text { sesuatu, dan kemudian ia } \\ \text { benar-benar berusaha dan } \\ \text { mewujudkan keinginannya } \\ \text { tersebut dengan tekad untuk } \\ \text { meraih hasil yang sempurna. } \\ \text { Namun, tak lama kemudian } \\ \text { seiring waktu berlalu, } \\ \text { ambisinya }\end{array}$

Semangatnya memudar dan kerjanya mulai lamban. Akhirnya, ia justru berhenti total sebelum semua rencananya bisa terwujud. Itulah tipu daya dan gangguan setan terkutuk. Setan selalu berusaha keras secara perlahan merasuk kedalam jiwa seseorang mukmin agar menjauhkannya dari segala jenis kebaikan. Dalam kondisi seperti ini, cara yang paling tepat memerangi setan adalah harus bergabung dengan kawan, saudara dan kenalan. Tujuannya adalah agar saling tolong-menolong dalam menghafal Al-Qur'an. Allah berfirman :

Artinya : "Tolong-menolonglah kamu dalam (mengerjakan) kebajikan dan takwa, dan jangan tolong-menolong dalam berbuat dosa dan pelanggaran. dan bertakwalah kamu kepada Allah, Sesungguhnya Allah amat berat siksa-Nya." (QS. Al- 
Maidah : 2) (Departemen Agama RI, 2010: 15)

Sebagaimana yang diceritakan oleh Kiai Ghozi Rofi'uddin kepada peneliti bahwa:

Rasulullah SAW bersabda : "Setan bersama orang yang sendirian. Dan ia akan menjauh dari dua orang". Jika anda menemukan dalam diri anda semangat yang tinggi dan membara untuk menghafal AlQur'an, disamping waktu yang luang dan cukup bergabunglah dalam sebuah kelompok bersama beberapa kawan atau saudara yang mendukung tujuan anda. (Kiai Ghozi Rofi'udin, 27 April 2017, jam $13.00 \mathrm{WIB})$.

Keenam, Menguatkan dalam shalat ialah Memanfaatkan shalat dengan mengulang dan memantapkan hafalan.

Hal ini juga dsampaiakan oleh Kiai Ghozi Rofi'uddin yang menyatakan bahwa:

Kalian boleh membaca atau mengulang hafalan sesuai dengan kemampuan kalian. Bila hanya mampu 1 atau 2 halaman per shalat, maka lakukanlah. Yang penting bukanlah terletak pada jumlah halaman yang bisa dibacadalam shalat, tetapi istiqamah. Intinya harus istiqomah dalam mengulang hafalan, berapa pun jumlah ayat yang bisa diulang. Dengan istiqomah, insyaAllah hafalan akan tetap melekat dalam ingatan. (Kiai Ghozi Rofi'udin, 27 April 2017, jam 13.00 WIB).
Ketujuh, Memahami Maknanya ialah Memahami isi atau kandungan ayat akan member kemudahan tersendiri dalam menghafal Al-Qur'an. Orang yang paham bahasa AlQur'an (Arab) biasanya lebih cepat hafal karena ia mengerti makna alur cerita ayat yang dihafal. Ia tidak sekedar mengandalkan kecerdasan otak, tapi juga pemahaman. Bagi yang tidak paham bahasa Arab, bisa menggunakan mushaf terjemahan biasa atau perkata yang sekarang sudah beredar dengan berbagai bentuk. Dengan memahami makna ayat yang dihafal, mengahafal itu akan terasa lebih mudah, cepat, dan menyenangkan. Kiai Ghozi Rofi'uddin yang menyatakan bahwa:

Tak bisa dipungkiri bahwa orang yang memahami makna dan kandungan ayat-ayat yang akan dihafal akan lebih mudah untuk menghafalnya. Khususnya, ketika menghafal surat-surat yang mengandung kisah atau ayat-ayat yang mempunyai sababun nuzul (sebab turun) yang sudah sangat popular. Di pondok ini, diadakan pelatihan terjemah Al-Qur'an bagi para santri. Ini bertujuan untuk memudahkan santri dalam menghafal AlQur'an. Jadi selain mereka hafal Arabnya, mereka juga bisa tahu artinya. (Kiai Ghozi Rofi'udin, 27 April 2017, jam 13.00 WIB) 
Hal senada diungkap oleh $\mathrm{M}$. Ridho'i kepada peneliti bahwa: Al-Qur'an itu sungguh luar biasa. Semakin dipahami maknanya makan kita akan semakin penasaran untuk mendalaminya. Susunan kalimatnya yang indah serta maknanya yang dalam membuat ayat-ayat Al-Qur'an begitu mempesona. Menghafal dengan pamahaman akan lebih membekas di hati dan lebih melekat di otak. Di pondok ini, ada pelatihan untuk penerjemahan Al-Qur'an yang biasa dikatak dengan Metode Tarjim Al-Qur'an. Metode ini sangan membantu kami, kami akan lebih mudah untuk mengahafal ayat-ayat AlQur'an karena kami sudah mengetahui terlebih dulu maknanya.( M. Ridho'i, 1 Mei 2017, jam 13.00 WIB).

Berdasarkan hasil wawancara dengan Pengurus Pondok pada tanggal 1 Mei 2017, faktor pendukung dalam menghafal Al-Qur'an antara lain : Pertama, Selalu mengikuti kegiatan-kegiatan yang berhubungan dengan AlQur'an. Kedua, Lingkungan banyak para penghafal. Ketiga, Mengikuti deresan Al-Qur'an diluar pondok atau diluar jam kegiatan.

Keempamt, Mengikuti perlombaan musabaqoh yang berada di Pondok agar bisa semakin aktif dalam mengulang-ulang hafalan Al-Qur'an. Kelima, Kembali kepada Himmah dan kemauan inisiatif pada anak itu sendiri. b. Faktor penghambat dalam menghafal al-Qur'an melalui metode tarjim

Berdasarkan hasil wawancara dengan Pengasuh Pondok, Ustadz dan para santri pada tanggal 15 April 2017, faktor penghambat dalam menghafal Al-Qur'an antara lain :

1) Kurang Perhatian

Secara sederhana dapat dikatakan bahwa konsentrasi tidak dapat terwujud tanpa adanya perhatian. Jika melakukan sesuatu yang penting tanpa ada unsur yang dapat membuat tertarik, maka harus memunculkan faktor yang menguatkan perhatian secara acak. Ini untuk melahirkan motivasi pada riri seseorang. Jika tidak, maka otak akan menetang dan enggan untuk berkonsentrasi.

2) Suka Menunda

Sebagian orang melakukan penundaan terhadap hal-hal yang tidak menarik bagi mereka, tanpa berpikir mengenai akibat yang ditimbulkan dari penundaan ini. Penundaan ini adalah ungkapan dari salah satu bentuk "rela dengan kegagalan kecil"

Waktu adalah umur kehidupan manusia di dunia. Ia adalah modal perdagangan manusia dengan Allah SWT. Karena itu, hindarilah sikap mengulur-ulur waktu dan menyibukkan diri dengan hal-hal yang memalingkan 
diri dari Al-Qur'an. Jangan biasakan mengatakan, "Besok saya akan menghafal". "Besok saya akan membaca", dan seterusnya. Sebab, menghafal kitabullah tidak dapat terlaksana dengan menyia-nyiakan waktu dan menuruti hawa nafsu.

Hal ini didukung oleh pernyataan Kiai Ghozi Rofi'uddin yang menyatakan bahwa:

Dalam menghafal juga perlu mengetahui sebab-sebab yang dapat menghambat atau faktor penghambat dalam menghafal AlQur'an. Adakalanya orang kurang menaruh perhatian terhadap hafalan. Akibatnya, tidak terbesit kesan yang kuat dalam pikirannya tentang menghafal. Dengan diadakannya Tarjim AlQur'an, diharapkan santri bisa lebih semangat dalam menghafal Al-Qur'an. Tapi perlu kita ketahui juga, kita harus memperhatikan keadaan lingkungan disekitarnya. Kalau temannya tidak rajin, anak akan mudah terbawa suasana. Seorang penghafal itu harus mempunyai target hafalan untuk mereka sendiri, mereka menarget hatam 2 atau sampai 3 tahun berarti mereka tidak boleh untuk menyia-nyiakan waktu. Maka dari itu, pengasuh, pengurus dan para ustadz/ah terus mengontrol anak-anak agar belajar disiplin dalam berbagai hal.(Kiai Ghozi Rofi'udin, 27 April 2017, jam 13.00 WIB).

3) Gangguan Lingkungan

Di antara berbagai penghalang tersebut adalah : hawa nafsu yang selalu condong untuk bersenangsenang dan benci terhadap sifat mujahadah (bersungguh-sungguh), setan yang selalu menghalangi untuk menghafal Al-Qur'an.

Hal ini didukung oleh pernyataan Ihya'ul Ulum yang menyatakan bahwa:

Anak-anak itu menganggap muroja'ah lebih memberatkan dari pada awal menghafal. Padahal tiap harinya diadakan mudarrosah dan muroqobah 1 juz untuk mengulang hafalan agar lebih terjaga. Selain itu ada pelatihan tarjim Al-Qur'an untuk memudahkan mereka dalam menghafal, karena dengan ini mereka akan mengetahui makna dari ayat yang dihafal. Anak-anak masih kurang mempunyai tekad dan niat yang lurus dalam menghafal Al-Qur'an. Kalau libur pondok dan tidak digunakan untuk kegiatan Al-Qur'an mereka akan merasa senang karena bisa bersenang-senang untuk sejenak. (Ihya'ul Ulum, 15April 2017, jam 13.00 WIB). 
4) Kurangnya Muroja'ah

Para ulama tafsir menjelaskan, manusia dinamakan insane yaitu berasal dari kata insanan yang artinya lupa. Sebab, manusia mempunyai sifat lupa. Karena itu, jika para penghafal Al-Qur'an lupa sebagian hafalannya, ia tidak perlu terlalu gelisah. Karena hal itu wajar bagi manusia. Lupanya Nabi SAW adalah menunjukkan bahwa beliau adalah manusia biasa. Tapi beliau adalah ma'shum dan imam bagi seluruh hafizh AlQur'an.

Sebagaimana penjelasan Ari Seno kepada peneliti bahwa: Al-Qur'an itu mudah dihafal, tapi kalau tidak dimuroja'ah akan cepat hilang dari ingatan kita. Maka dari itu hilangkan rasa malas dalam diri kita, perbaiki niat kita dari sekarang. Tetaplah mengulang hafalan secara terus-menerus dan jagalah apa yang telah dihafal dengan terus mengulang hafalan, mendengarkan dan meminta saudara kita untuk mendengarkan hafalan kita. Untuk lebih memudahkan kita dalam mengingat hafalan, kita bisa membacanya disaat sholat. Semoga Allah SWT menjadikan kita sebagai manusia ahli Al-Qur'an dan manusia yang paling dekat di sisi-Nya. (Ari Seno, 21
April 2017, jam 13.00 WIB).

\section{Analisis}

1. Implementasi Metode Tarjim

Metode Tarjim merupakan kajian tata bahasa asing yang menekankan analisa tata bahasa, penghafalan kosa kata, penerjemah wacana, dan latihan menulis. Metode ini mementingkan kecakapan membaca, menulis, dan terjemah. Bisa disebut klasifikasi dari segi isim, fi' $i l$ atau huruf.

Penerapan Metode Tarjim di Pondok Pesantren Tahfidzul Qur'an Safinatul Huda III yaitu suatu model pembelajaran dengan cara membentuk kelompok. Satu kelompok ini maksimal 20 orang yang di ajar oleh satu Ustadz/ah.

Penerapan Metode tarjim ini mempunyai buku atau media belajar dalam memahami AlQur'an secara lafdhiyah atau perkata (kamus Lafdzul Qur'an dan program Pelatihan Terjemah Al-Qur'an). Dalam buku tersebut lafazh yang tercetak merah adalah kata baru, karena di dalam AlQur'an banyak kata yang diulangulang, maka semakin banyak yang dipelajari semakin sedikit lafadz yang tercetak merah, itu berarti semakin mudah untuk kita memahaminya. Kamus tersebut dibagi secara per juz, karena setiap juz mempunyai klasifikasi lafadz yang berbeda. Seperti juz 1 lafdhiyah atau perkata, terjemah bahasa Indonesia dan klasifikasi lafadznya dari segi isim, fi'il atau huruf. 
Penerapan metode tarjim di Pondok Pesantren Tahfidzul Qur'an Safinatul Huda III Bandung Diwek Jombang sebagai berikut : Pertama, Satu kelas maksimal 20 santri yang dibawai oleh satu ustadz /ah. Kedua, Menyiapkan Mushaf beserta kamus Lafdzul Qur'an sebelum memulai menerapkan metode tarjim. Ketiga, Membaca dengan tartil 1 kaca atau satu halaman yg akan diterjemahkan. Keempat, Membaca satu ayat kemudian diterjemahkan perpotong. Kelima, Setelah menerjemahkan perpotong, dilanjutkan menerjemah secara langsung dalam satu ayat. Keenam, Jika ada arti yang lupa diperbolehkan untuk membuka kamus Lafdzul Qur'an. Ketujuh, Setelah selesai penerjemahan satu halaman, maka diulang kembali dari awal dengan mengartikan per ayat. Kedelapan, Untuk mengetahui seberapa keberhasilan santri dalam menghafal melalui metode tarjim, maka akan diadakan evaluasi pada tiap pergantian juz.

Sedangkan Pengaplikasian Metode Tarjim dalam menghafal Al-Qur'an di Pondok Pesantren Tahfidzul Qur'an Safinatul Huda III Bandung Diwek Jombang melalui takrir (mengulang hafalan), antara lain :

a. Takrir sendiri

Santri yang menghafal AlQur'an di Pondok Pesantren Tahfidzul Qur'an Safinatul Huda III memanfaatkan waktu untuk takrir dan menambah hafalan. Hafalan yang baru di takrir santri minimal dua kali sehari dalam jangka waktu satu minggu. Sedang hafalan yang lama di takrir ssantri setiap hari atau dua hari sekali. Artinya semakin banyak hafalan santri maka semakin banyak pula waktu yang dipergunakan untuk takrir.

b. Takrir dalam sholat

Santri yang menghafal AlQur'an di Pondok Pesantren Tahfidzul Qur'an Safinatul Huda III bisa memanfaatkan hafalannya sebagai bacaan dalam shalat, baik sebagai imam maupun dalam shalat sendiri. Selain menambah keutamaan (pahala), cara demikian juga akan menambah kemantapan hafalan santri.

c. Takrir bersama

Santri yang menghafal AlQur'an di Pondok Pesantren Tahfidzul Qur'an Safinatul Huda III melakukan takrir bersama dengan dua teman atau lebih. Dalam takrir ini setiap orang yang membaca materi takrir yang ditetapkan secara bergantian, misalnya masing-masing satu halaman, dua halaman atau ayat per ayat. Ketika seorang santri membaca, yang lain mendengarkan dan membetulkan jika ada yang salah.

d. Takrir kepada instruktur atau guru

Santri yang menghafal AlQur'an di Pondok Pesantren Tahfidzul Qur'an Safinatul Huda III harus selalu menghadap instruktur atau guru untuk takrir hafalan yang sudah diajukan. Materi takrir yang dibaca harus lebih banyak 
dari pada materi tahfidz, yaitu satu banding sepuluh. Artinya, apabila santri sanggup menyetorkan hafalan baru dua halaman setiap hari, maka harus diimbangi dengan takrir 20 halaman (satu juz).

Pelaksanaan kegiatan metode tarjim yang optimal akan terjadi jika ada interaksi positif antara pengasuh, ustadz/ah dan santri. Pengasuh sebagai teladan dan juga fasilitator yang harus dapat memfasilitasi santri dalam mengembangkan diri dengan harapan proses dan hasil menghafal Al-Qur'an di Pondok Pesantren Tahfidzul Qur'an Safinatul Huda III dapat memberikan pengalaman dan kesan yang baik dan mampu membentuk kepribadian santri secara hamilil Qur'an hafidhul Qur'an lafdhan wa ma'nan wa 'amalan.

Ustadz/ustadzah adalah orang yang pertama menjadi dasar penentu keberhasilan santrinya, berhasil tidaknya hafalan santri tergantung pengembangan pengajaran ustadz/ustadzah. Selain memberikan motivasi kepada santri, ustadz/ustadzah juga harus memberikan pengkajian ilmu tajwid, sehingga santri tidak hanya lancar menghafal Al-Qur'an.

Yahya Abdul Fattah Az Zawawi mengatakan kepada calon penghafal Al-Qur'an bahwa Selama Anda dapat menemukan guru mengaji yang ahli atau Qori' yang bagus bacaannya, maka hal itu akan sangat bagus. Guru tersebut dapat mendengarkan bacaan Anda dan membenarkan kesalahan Anda serta mengajari Anda tentang ilmu tajwid. Hal ini sangat bermanfaat bagi diri Anda, sehingga Anda bisa bersama para malaikat Safaratul Kiramil Bararah (Yahya Abdul Fattah Az-Zawawi, 2013)

Sesuai dengan teori bahwa penerapan Metode Tarjim itu tidak lepas dari peran Pengasuh dan Ustadz/ah. Pengasuh sebagai teladan dan juga fasilitator yang harus dapat memfasilitasi santri dalam mengembangkan diri dan Ustadz/ustadzah adalah orang yang pertama menjadi dasar penentu keberhasilan santrinya.

2. Faktor pendukung dan penghambat metode tarjim

Setiap jalan menuju kebaikan mesti dipenuhi duri yang menghalangi pejalan kaki untuk sampai pada tujuan. Menghafal Al-Qur'an merupakan aktifitas yang sungguh sangat mulia, baik dihadapan Allah maupun dalam pandangan manusia. Sedemikian banyak waktu yang tercurah, konsentrasi pikiran yang terpusat, bahkan tenaga dan biaya juga ikut terkuras. Semua diniatkan untuk menggapai ridlo Allah, tanpa ada hasrat sedikitpun menjadikannya sebagai sumber penghasilan ataupun sanjungan. Dibalik kilau cahaya kemuliaan tersebut, tersembur pula serabut-serabut duri godaan yang senantiasa menghadang sewaktu-waktu. Jadi, siapapun yang pernah menjalani 
proses menghafal Al-Qur'an bisa dipastikan pernah merasakan pahitnya cobaan dan manisnya godaan. Tentu, jenis cobaan dan godaan tiap-tiap orang berbeda. Adapun kemampuan menghalau godaan itu sangat tergantung pada tingkat ketulusan niat dan kedalaman iman yang terpatri dihati.

Menghafal Al-Qur'an merupakan ibadah yang sangat mulia. Kegiatan tersebut termasuk kesibukan yang terpuji. Lebihlebih jika kegiatan tersebut dibarengi dengan niat mendekatkan diri kepada Allah SWT dan sekaligus merenungi ayat-ayat-Nya, kegiatan ini akan menjadi ketaatan yang berpahala besar. Persiapan yang matang dengan menjaga etika sebelum dan ketika menghafal Al-Qur'an diharapkan akan memberikan hasil yang sempurna.

Menghafal Al-Qur'an di Pondok Pesantren Safinatul Huda III, tidak lepas dari faktor pendukung dan penghambat yang berkenaan dengan proses menghafal AlQur'an. Diantara faktor yang mendukung antara lain : Memperbaiki bacaan sebelum menghafal, Menggunakan satu mushaf Al-Qur'an, Menentukan target hafalan setiap hari, Melazimi halaqah tahfizh, Membantu menguatkan dalam shalat.

Menurut Wiwi Alawiyah Wahid, hal yang dipersiapkan sebelum menghafal Al-Qur'an yaitu Niat yang ikhlas, meminta izin kepada orang tua atau suami, mempunyai tekad yang besar dan kuat, istiqomah, harus berguru kepada yang ahli, mempunyai akhlak terpuji, berdoa agar sukses menghafal Al-Qur'an, memaksimalkan usia, dianjurkan menggunakan satu jenis AlQur'an, dan lancar membaca AlQur'an. (Wiwi Alawiyah Wahid, 2012).

Hal senada diungkap oleh Kiai Ghozi Rofi'udin bahwa sebuah sarana yang tidak akan pernah siasia ialah berdo'a kepada Allah SWT dengan tulus ikhlas. Memohon kepada Allah SWT agar Dia menganugerahkan nikmat hafal Al-Qur'an pada diri santri. Selain itu menjadikan niat santri ikhlas karena Allah SWT semata, serta memberikan kemudahan bagi santri dalam beramal.

Adapun sebab-sebab yang membantu dalam menghafal AlQur'an antara lain mencintai AlQur'an, mendengarkan bacaan kaset-kaset Al-Qur'an, membantu menguatkan hafalan dalam shalat, menghilangkan penyakit hati (sombong, iri, dengki dll), tidak menunda-nunda waktu untuk memulai menghafal, memperhatikan ayat-ayat yang memiliki kesamaan lafadz, menguasai ilmu tajwid, memahami makna sebelum menghafal dan sering mengulangulang bacaan.

Begitu juga sebaliknya, setiap kegiatan yang kita lakukan pasti terdapat faktor yang menghambatnya. Dalam usaha pasti ada hambatan, baik yang datangnya dari diri sendiri maupun dari luar. Faktor penghambat atau kendala dalam menghafal Al-Qur'an di Pondok 
Pesantren Tahfidzul Qur'an Safinatul Huda III terbagi menjadi dua yakni faktor internal dan faktor eksternal, yang dimaksud faktor internal adalah faktor yang timbul dari dalam individu penghafal Al-Qur'an seperti Kurang Perhatian, Suka Menunda, kenakalan santri yang melanggar tata tertib pondok. Yang dimaksud faktor eksternal adalah faktor yang timbul dari lingkungan, masyarakat dan keluarga.

Yahya Abdul Fattah Az Zawawi mengatakan kepada calon penghafal Al-Qur'an bahwa Selama Anda dapat menemukan orang yang baik untuk dijadikan teman dalam menghafal AlQur'an bersama Anda, maka hal itu akan sangat membantu. Usahakan mencari teman yang yang setara atau lebih baik dari kemampuan Anda. Hal ini akan sangat bermanfaat bagi diri Anda, diantaranya Anda memiliki teman yang senasib sepenanggungan. Teman yang ikhlash karena Allah, mencintai Anda, dan Anda pun mencintainya karena Allah. Ia akan bersama Anda karena Allah dan berpisah dengan Anda juga karena Allah. Ia juga menjadi penolong dan penyemangat bagi diri Anda, sebaliknya, Anda juga menjadi penolong dan penyemangat baginya untuk menghafal Al-Qur'an dan tetap konsisten. Anda dapat mendengarkan hafalannya dan ia pun jugadapat mendengarkan hafalan Anda, sehingga Anda berdua dapat saling membenarkan apabila ada kesalahan.(Yahya Abdul Fattah Az-Zawawi, 2013).
Menurut Mukhlisoh Zawawie bahwa Hambatan-hambatan yang dihadapi oleh calon seorang hafidz yaitu: sibuk dan tidak memiliki banyak waktu, hati tidak jernih dan kurang fokus karena problematika hidup, bosan dan malas ketika memulai hafalan atau ditengah hafalan, faktor usia, tidak percaya diri karena hafal AlQur'an adalah anugerah Allah, lemah ingatan, dan takut lupa dan berdosa.(Mukhlisoh Zawawie, 2011).

Hal senada diungkap oleh Kiai Ghozi Rofi'udin bahwa dalam menghafal juga perlu mengetahui sebab-sebab yang dapat menghambat atau faktor penghambat dalam menghafal AlQur'an. Adakalanya santri kurang menaruh perhatian terhadap hafalan. Akibatnya, tidak terbesit kesan yang kuat dalam pikirannya tentang menghafal. Tapi perlu kita ketahui juga, kita harus memperhatikan keadaan lingkungan disekitarnya, masih ada santri yang terbawa dengan lingkungannya. Kalau lingkungannya baik, memungkinkan santri akan lebih semangat dalam menghafal. Tapi kalau lingkungannya kurang kondusif, yang ada santri hanya akan bermalas-malasan dan hanya suka bercanda dengan temantemannya. Karena itulah pintarpintarnya santri untuk meluruskan. (Kiai Ghozi Rofi'udin, 27 April 2017, jam 13.00 WIB).

\section{Kesimpulan}

Berdasarkan
pemaparan dari semua 
sebelumnya, maka dapat ditarik kesimpulan beberapa hal penting dan dominan yang disesuaikan dengan fokus penelitian yaitu sebagai berikut:

1. Implementasi Metode Tarjim dalam menghafal Al-Qur'an di Pondok Pesantren Tahfidzul Qur'an Safinatul Huda III yaitu suatu model pembelajaran dengan cara membentuk kelompok. Satu kelompok ini maksimal 20 orang yang di ajar oleh satu Ustad atau ustadzah. Sedangkan Pengaplikasian Metode Tarjim dalam menghafal Al-Qur'an di Pondok Pesantren Tahfidzul Qur'an Safinatul Huda III Bandung Diwek Jombang melalui takrir (mengulang hafalan), antara lain Pertama, Takrir sendiri, Kedua, Takrir dalam sholat. Ketiga, Takrir bersama. Keempat, Takrir kepada Instruktur atau Guru.

2. Faktor Pendukung dan Penghambat Menghafal AlQur'an Melalui Metode Tarjim
a. Faktor
Pendukung
menghafal
Al-Qur'an
melalui metode tarjim
antara lain Pertama,
Memperbaiki bacaan
sebelum menghafal.
Menggunakan satu mushaf
Al-Qur'an.
Kedua,
Menentukan target hafalan setiap hari. Ketiga,
Melazimi halaqah tahfizh.
Keempat, Membantu menguatkan dalam shalat

b. Faktor Penghambat

menghafal Al-Qur'an melalui metode tarjim terbagi menjadi dua antara lain : Pertama, Faktor

Internal yang dimaksud adalah faktor yang timbul dari dalam individu penghafal Al-Qur'an seperti kurang perhatian, suka menunda, kenakalan santri yang melanggar tata tertib pondok. Kedua, Faktor Eksternal yang dimaksud adalah faktor yang timbul dari lingkungan, masyarakat dan keluarga.

\section{Daftra Pustaka}

Abdul, Yahya Fattah Az-Zawawi, Metode Praktis Cepat Hafal AlQur'an, Solo:Pustaka Iltizam.

Abdul,Yahya Fattah Az-Zawawi, 2013, Metode Praktis Cepat Hafal AlQur'an, Solo:Pustaka Iltizam

Alawiyah,Wiwi Wahid. 2012, Cara Cepat Bisa Menghafal Al-Qur'an, (Jogjakarta: DIVA Press

Departemen Agama RI, 2010, Mushaf Daliyah Al-Qur'an Terjemah da $n$ Tafsir untuk Wanita, Bandung: Jabal,.

Khalil, Manna al-Qattan. Studi ilmu-ilmu Al-Qur'an. Bogor: Litera Antar Nasa Halim Jaya, 2014.

Majdi, Al-Hafizh. 9 Langkah Mudah Menghafal Al-Qur'an. Solo : Aqwam, Ubaid 2014.

Qosim, Amjad. Meski Sibuk pun Bisa Hafal Al-Qur'an. Solo : Al-Kamil Solo, 2013.

Saied, Al-Hafizh. 2016, Karantina Hafal Al-Qur'an Sebulan. Solo : Alam AlMakhtum Pena

Zawawie, Mukhlisoh. 2011, P-M3 AlQur'an Pedoman Membaca, Mendengar, dan Menghafal AlQur'an, Solo:Tinta Medina 